\title{
TÉRSZERKEZETI VÁLTOZÁSOK A POLGÁROSODÓ KISALFÖLDÖN
}

\author{
(Changes in the Spatial Structures in the Kisalföld during the \\ Process of Middle-Classing)
}

\author{
GYÖRI RÓBERT
}

\section{Bevezetés}

Tanulmányunkban egy feltételezett történeti régió rekonstruálására és térszerkezeti változásainak felderítésére vállalkozunk. A magyar szakirodalomban, mind a geográfiában, mind a történettudományban ritka a történeti tájegységek, régiók monografikus jellegủ feldolgozása, és ez tőlünk nyugatabbra sem közkedvelt vizsgálódási terep (Tímár 1991). Nem véletlen ennek a vizsgálati területnek az elhanyagolása. A magyar történettudomány nem rendelkezik a térre vonatkozó szilárd fogalomrendszerrel, a regionális kutatások alapjául szolgáló térszemlélet pedig nem alakult ki (Faragó 1984). Történészeink érdeklődése eddig kevésbé fordult a múlt térbelisége felé. Geográfiánk viszont az utóbbi időben egyre nagyobb élénkséggel vizsgál történeti jelenségeket, igaz, egyelöre régiórekonstrukciókkal még adós maradt. E tanulmány is ebbe az élénkülö munkába szeretne bekapcsolódni. A tanulmány elkészítésének gondolatát az az elképzelés motiválta, hogy a jelenre végrehajtott regionális kutatások megfelelő statisztikai és egyéb források megléte esetén végrehajthatók a múlt tereire is.

A tanulmány első részében a címben szereplő fogalmakra térünk ki, részletesen kifejtve, mit értünk polgárosodás, térszerkezet alatt, mit jelent, és hogyan értelmezhető a Kisalföld, mint történeti térelem. A második részben arra keressük a választ, hogy a Kisalföld, mint egységes régió mikor jött létre, és jogos-e a régió fogalom használata. A harmadik rész a polgárosodás elötti térszerkezetet próbálja vázolni, különös figyelemmel kísérve a térszerkezetet alakító jelenségeket. A negyedik rész pedig a polgári korszak Kisalföldjéröl szól, az új térformáló erőket veszi számba, és próbálja összefoglalni hatásukat. ${ }^{1}$

\section{Alapfogalmak}

\section{A polgárosodás}

Tanulmányunk szủkebb időkeretéül a reformkortól az első világháború kitöréséig terjedő időszakot választottuk. Ezen időszakot tekintik Magyarországon a polgárosulás, a modernizáció időszakának. A polgárosulás fogalma alatt több jelenséget érthetünk. Az 1848-as áprilisi törvények megteremtették a polgári állam kereteit, 
létrehozták az egységes polgári társadalom kialakulásához szuakséges jogi feltételeket, szabad utat nyitottak a vállalkozások és pénzmozgások elött. Ennek a folyamatnak része volt a polgári államigazgatás kialakitása. Ez Magyarországon a kiegyezés után, kitüntetetten az 1860-as évek második felében és az 1870-es évtizedben játszódott le. Új intézmények alakultak, kiépült a polgári közigazgatás, ez a falu-város kapcsolatok megváltozásához és a városok szerepének átalakulásához vezetett. Beluszky Pál statisztikai vizsgálatok segítségével kimutatta, hogy a városi szerepkörök közull (elsősorban a hierarchia alacsonyabb szintjein) ezen új polgári elemek meghatározóak lehettek, ez a változás volt a településhálózat átrendeződésének az egyik meghatározó eleme. A városhierarchia élén kevés olyan várost találunk, amely magas szintủ közigazgatási szerepet ne töltött volna be; ez a központi szerepkör az esetek többségében a vezető városi funkció. A polgári igazgatás centrumokat igényel, azonban ennek fejlesztő ereje nem szerves, hanem felső szintü döntések erejével preferál településeket (Beluszky 1990, 15; 21). A polgári igazgatás intézményeinek jelenléte sok egyéb olyan intézmény megtelepedését teszi szükségessé és lehetővé (pl. járásbíróságok melletti ügyvédek, közjegyzők jelenléte), amelyek ezt a folyamatot még hangsúlyosabbá teszik (Beluszky 1995, 449).

A polgárosulás fogalma társadalmi átalakulást takar. Erdei Ferenc a magyar parasztság polgárosulásáról írva a polgárosulás lényegének azt tartja, hogy a rendi társadalom keretei közül kikerülő parasztság része lesz az egységes polgári társadalomnak, a rendi tagolódást a polgári társadalomra jellemző vagyoni rétegződés (osztálytársadalom) váltja fel. Ez a változás természetesen a mentalitás és az életmód átalakulásával is társul. A folyamat már a polgári forradalom után elkezdődött, azonban meglehetősen lassú, ugyanis a magyar társadalom nem tökéletes polgári társadalom, csak „nagyjában” az, rendies elemek jellemzik, a parasztság pedig ebbe a rendies (polgári) társadalomba asszimilálódik (Erdei 1941, 81-83). A változás nemcsak időben és társadalmi rétegenként eltérö módon húzódik el, hanem térbelileg is szétterül. Ezt a térbeli változást jól mérhetjük a népi kultúra állapotán, egyes (modern) jelenségek diffúziojjának, archaikus jelenségek megmaradásának területi vizsgálatával (Kósa 1998, 43; 60-62). A polgárosulás egyik legfontosabb mozzanatának mi is ezt a változást tekintjük, kibővítve azzal, hogy nemcsak a parasztság, hanem az egész magyar társadalom átalakulását értjük alatta. A társadalmi átalakulás folyamatossága és megszakítatlansága egészen az első világháborúig tartott. A társadalmi változást olyan jogszabályok készitették elỏ, amelyek pl. lehetơvé tették a népesség nagyobb arányú társadalmi és térbeli mobilizációját, előfeltételezték a dualizmuskori gazdasági élénkülést és ezekkel párhuzamosan a területi átrendezödést (Mendöl 1943, 122).

A változás harmadik fontos elemének pedig a gazdaság átalakulását, modernizálódását (kapitalizálódását) tekintjük. Ez hosszabb időtávú folyamat, a dualizmuskori fellendülést elökészítik a XVIII. sz. és a reformkor gazdasági folyamatai és törvényhozása. Ebben az időszakban teremtődik meg a modern gazdaság, a termelés minden ágában kommercializálódik, piacra termel, forradalmi változások zajlanak a 
Tér és Társadalom, 13. 1999. 4. 77-106. $p$.

közlekedésben (vasutak megjelenése), intenzifikálódik a mezőgazdaság, a gyáripar egyre nagyobb teret nyer a kézmüipar rovására (Kövér 1991, 35-37).

A korszak kezdöpontjául természetes módon adódna egyrészt a polgári forradalom idópontja, másrészt a kiegyezés dátuma. Nem hinnénk, hogy mereven évszámhoz kellene kötődnünk, a vizsgált jelenségekben nem jelentenek ezek a dátumok olyan éles cezúrát. Például a gazdaság szempontjából fontos polgári intézmények törvényes keretét a neoabszolutista kormányzat teremti meg az 1850-es években, a polgári közigazgatás kiépúlése pedig az 1870-es években zajlik le (GyániKövér 1998, 30; 52-53). Rendszeres statisztikai adatok a kiegyezéstől kezdve állnak rendelkezésünkre, egyes jelenségek vizsgálatát csak ettől az időszaktól végezhetjük el, így tanulmányunk nagy része is a kiegyezés utáni időszakkal foglakozik. Azonban a polgári korszakot megelőzỏ időszakra is vissza kell nyúlnunk, hogy azokat a hosszú távú folyamatokat átfogjuk, amelyek évszázadokra irányadóak voltak a térszerkezet alakulásában.

\section{Térszerkezet a múltban}

Mi a térszerkezet? Minden emberi tevékenység használja a teret. Az emberek a munkavégzés, kereskedés, kulturális tevékenység, szórakozás, üdülés stb. során a tér egyik pontjáról a másikra utaznak. A gyakran ismétlődő ugyanolyan irányú mozgások jellegzetes térkapcsolatokat alakítanak ki, ugyanilyen térkapcsolatokat hoz létre nemcsak a személyhez kötődő térhasználat, hanem az áruk, szolgáltatások forgalma és a kommunikáció is (Nemes Nagy 1998, 207-208; 222-225). A térkapcsolatok ősszessége rajzolja fel a térszerkezet vázát, amely kapcsolatok egyes pontokban sürủsödnek, máshol ritkulnak vagy hiányoznak, hálózatot hoznak létre; ez a térszerkezeti egységek elkülönítésének alapja. Térszerkezeti egységnek tekintethetjük a (társadalom)földrajzilag homogén teruleteket is, az ezeken belül szervezödó jellegzetes kapcsolatok miatt. Pl. egy etnikailag vagy vallásilag homogén terület gyakran meghatározza az emberek mozgását is, pl. házasodási körzetet is kirajzol. A különbözö térszerkezeti egységek hierarchikus rendet alkotnak. A legalacsonyabb fokú egység a központi telepưlés körül szerveződő vonzáskörzet. Ritkábban igénybe vett szolgáltatások, funkciók már csak kevesebb településen fordulnak elö. Egy nagyobb város ilyen szolgáltatását több kisebb város vonzáskörzetének lakossága is igénybe veszi, ez is egyfajta térszerkezeti egység. A térszerkezeti egységek hierarchiájának kialakulása történeti folyamat, elsősorban a munkamegosztás szélesedésével, a lakosság igényeinek növekedésével következik be (Mendöl 1963, 428).

Léteztek-e a múltban a maival összevethetỏ térkapcsolatok, beszélhetünk-e tơrténeti terek kapcsán térszerkezetröl? Mendöl Tibor érdekes kuilönbségtételt tesz, amikor a telepulésállomány és a településhálózat különbségéröl ir. Településállomány vizsgálatán a telepulések térbeli elrendeződését, és ennek más jelenségek térbeliségéhez való viszonyítását érti, míg a telepuiléshálózat vizsgálata a telepưlések egységének, rendszerének, kapcsolathálózatának, hierarchikus rendjének vizsgálatát jelenti. Mendöl arra a megállapításra jut, hogy a múltban nem beszélhetünk telepü- 
léshálózatról, csak -állományról (Mendöl 1963, 490-492). Mindez azt sugallja, hogy a térszervező folyamatok csak a modern gazdaság létrejöttével teremtődnek meg, a városhálózat kialakulása is ehhez köthetö.

Azonban a múltban is léteztek térkapcsolatok, a jellegzetes térhasználat kialakított hálózatokat, még ha más jelenségekhez kötődött is ez a térhasználat, mint ma. Például a falu-város kapcsolat jellegzetes formája a piacok látogatása volt, a falusiak mezőgazdasági termékeiket értékesítették a városi piacon, $\mathrm{s}$ a városban elégítették ki iparcikk-szúkségleteiket. A város közigazgatási, igazságszolgáltatási központ szerepe szinte teljesen hiányzott, ezt sok helyen a földesúri birtokközpontok, az uradalmak töltötték be. A kereskedelmi kapcsolatok irányát megkötötte a közlekedési eszköz használati lehetősége (hajózható folyó, járható út stb.). Ez markáns térpályákat jelölt ki. Tehát a múltban is létezett térszerkezet (mert léteztek térkapcsolatok), egyes jelenségeknek megvolt az ónálló térszerkezetük. A múltban az egyes térszervező erök szorosabban összekapcsolódtak, egységesen müködtek (pl. a nagybirtokszervezet igazgatási, bíráskodási, munkaszervezési, terménykereskedelmi szerepe), nehezebben szétválaszthatóak, ami a térszerkezeti egységek koherenciáját még szorosabbá tette (Faragó 1984, 13).

\section{A vizsgálat tere: a történeti régió}

Először arra a kérdésre kerestük a választ, mit jelent a régió a geográfiában és a történettudományban. A modern regionális földrajz megteremtése a századforduló francia geográfusának, Vidal de la Blache-nak köszönhető. Kutatásai a tájak sajátosságaira irányultak, mủvei a táj individualitását emelték ki (Probáld 1995, 36). A géographie humaine regionális módszere egyáltalán nem hasonlított a korábbi, mindent számba vevő katalógusszerủ állam- és tájismékhez. Vidal de la Blache elsősorban 'personnalité'-ként vagy 'individualité'-ként értékelte a földrajzi teret. A fóldrajzi tér individualitása Vidal de la Blache szerint nemcsak a természetfơldrajzi ismertetőjegyeinek egyveretűségében mutatkozik meg, hanem történeti - azaz gazdasági és társadalmi - jelenségekben is, amelyek az emberek térkapcsolataira vezethetők vissza, és amelyek együttes hatása rajzolja meg a régiót, ezek adják meg a tér individualitását. A régiót Vidal de la Blache a tér és az ember interakciójának eredményéként létrejött egységnek tekintette. Ez a regionális szemlélet rendkívül termékenynek bizonyult: a francia történettudomány megújulásában betöltött szerepe megkérdőjelezhetetlen, az Annales iskola képviselői az emberföldrajz hatására vágtak bele modern regionális történeti monográfiáik megirásába (pl. Marc Bloch: Ile de France) (Kronsteiner 1989, 62-66). A regionális feldolgozási módszer azonban nem lett általános sem a külfôldi, sem a magyar történeti irodalomban. Nem utolsó sorban azért, mert a regionális földrajz szerepe a geográfián belül is megkérdőjelezödött (Probáld 1995, 43-48; Tímár 1991, 13). Az elmúlt évtizedekben azonban újraértékelödött a regionális földrajz jelentősége megújult értelmezési keretekkel, modern feldolgozási eszkőzökkel. A modern regionális fỏldrajz a régió fogalmán az alábbiakat érti: a fơldrajzi jelenségek vizsgálatánál kirajzolódnak a 
Tér és Társadalom, 13. 1999. 4. 77-106. p.

jelenségek valóságos szerveződését tükrözö, összefüggő térbeli egységek. A formális körzetek alapját egy vagy több jelenségưk homogenitása, és környezetưktől való elkullönülése adja; a funkcionális körzeteket a bennük zajló folyamatok, mozgások, kölcsőnhatások összetartó ereje építi fel. Ténylegesen létező egységekről van tehát szó, nem pedig a kutatók által teremtett konstrukcióról. A komplex földrajzi régiókat a környezetüktöl elkủlönító homogenitás és sokrétü, belső összetartó kölcsönhatások egyuittesen jellemzik. A régiók általában az emberek tudatában is testet öltenek, illetve létrejöttükben-fejlódésükben szerepet kaphatnak hatalmi-politikai tényezők is. A táj fogalma is pontosodott, használati köre leszükült. Ma a táj természetföldrajzi kategória, léte a természeti tényezők homogenitásán és kölcsönhatásán nyugszik, alapja lehet a társadalomföldrajzi régiónak, de az azonosság nem szuikségszerü, a jelenhez közeledve gyengül a társadalomföldrajzi régiók természetföldrajzi alapú meghatározottsága (Probáld 1995, 41).

Láthatjuk tehát, hogy a mai térhasználat kialakít elkülöníthető téregységeket, $\mathrm{s}$ azt is, milyen közelítésmódokkal lehet ezeket vizsgálni. A történeti régiók vizsgálatánál szembe kell néznünk egy fontos kérdéssel: a múlt valóságában léteztek-e ilyen típusú homogén, illetve funkcionális terek, vagy ezeket a kutatás hozza-e létre, hogy vizsgálódását megkönnyítse? Robert Butlin amellett foglal állást, hogy a múltban nincsen a régióknak (körzeteknek) egy abszolút változatlan rendszere, a régiókat mi teremtjük, ahogy a múltban élök is teremtették ezeket, amikor benne élöknek tudták magukat (Butlin 1990, 1). Az ,új történeti földrajz" irányzatának egyik fontos tétele, hogy a történelem országhatárokhoz, régióhatárokhoz igazodó vizsgálata mesterséges, ezek csupán operacionális fogalmak, a kutatásnak hangsúlyozottan a telepuléshierarchia, a struktúra felé kell fordulnia, a társadalmi jelenségeket például a telepuléshierarchia mentén kell vizsgálnia (Tímár 1991, 17-21; Gyáni-Kövér 1998, 50).

Számtalan történeti vizsgálat van azonban, amely létező területi egységeket különített el. A néprajztudományban hosszú múltra tekintenek vissza azok a kísérletek, amelyek Magyarország területét néprajzi szempontok alapján tájakra tagolják. A terminológia nem egységes, a néprajzi csoport, táji csoport, etnikai csoport fogalmak értelmezéséről Kósa László munkája tájékoztat. Meg kell említenünk, hogy a néprajz az, amely térfelosztásánál a legerősebben figyelembe veszi az embercsoportok tájakhoz, táji csoportokhoz való mentális kőtődését („mi-tudat”) (Kósa 1998, 16-24). A néprajzosok táj, illetve tájhoz kőtődő csoport lehatárolásai elsősorban a formális régiólehatárolások eszközeivel élnek, az ezeket egymástól élesen elkülönítö jelenségek vizsgálata révén. Az etnográfusok definíciói közül a funkcionális régiószemlélethez legkőzelebb az Andrásfalvy Bertalan által használt terminusok állnak. A kistáj szakosodott falvak csoportja, amelyek a területi munkamegosztást felépítik. Ez a kistáj nem homogén: természeti és ezzel összefüggő (mezö)gazdasági kủlönbözőségei kiegészitik egymást. A kistáji munkamegosztás akkor lazul fel, amikor kialakul az árutermelés és a pénzhasználat, az egymást kiegészitő termékekre már nem lesz kölcsönösen szuikségưk. A régió a kistáji tagolódást időben felváltó folyamat során jön létre, amikor a falu-város kapcsolatrendszer alakítja a területi 
munkamegosztást, városi központ és (kulturális) körzete alkotnak egy régiót. A szétesỏ táji munkamegosztás helyett a város szervezi a teret (munkába járás, kulturális kapcsolatok stb.). A táji szakosodás helyébe a várost mezőgazdasági termékekkel ellátó falvak körzete és a körzetet iparcikkekkel, szolgáltatásokkal terító város kettőse lép. A falvak, kistájak közigazgatását a korábbi vásáros helyek, mezővárosok átruházzák a régió központját jelentő városra. A régió elhomályosítja az egykori kistájak keretét, a központtól mért távolság alapján elkülönülö zónák, övezetek rendje építi fel (Andrásfalvy 1980, 51-55). Andrásfalvy a történeti térszerkezeti változások egyik legkarakterisztikusabb mozzanatát írja le. A térrel foglalkozó kutatások egyik legfontosabb feladata lenne ennek a váltásnak a területenként eltérő időpontját meghatározni.

A történészek érdeklődése - elsősorban a geográfia eredményeitöl ösztönözve - a hetvenes évektöl már a funkcionális körzetlehatárolás felé fordult. Ezek között az egyik legalaposabb - módszereiben Magyarországon úttörő (faktoranalízis stb.) Bácskai Vera és Nagy Lajos XIX. sz.-i városhierarchia elemzése. A szerzőpáros az 1828-as összeírás segítségével feltérképezte a korszak falvainak piacközpontjait, ennek segítségével különböző intenzitású vonzáskörzeteket határolt le, megállapította a funkcionális értelemben városi települések számát, és hierarchiájuk felderitésére is kísérletet tett (Bácskai-Nagy 1984). Funkcionális körzetet nemcsak város szervezhet maga köré. Andrásfalvy kistáj-definíciója azt is bemutatja, hogy társadalomfơldrajzi értelemben vett régiót nemcsak városi funkciójú központ létesithet maga körül. A feudális nagybirtokok nemcsak gazdaságszervezési, hanem igazgatási, bíráskodási, társadalomszervezési funkciót is betőltöttek, területük igy komplex egységet alkotott. A falu-város területi munkamegosztás kialakulása elötti időszakban a térszervezés funkcióját az uradalom is elláthatta, ellátta (Faragó 1984; Gyáni-Kövér 1998).

Tóth Tibor is határozottan cáfolja, hogy csupán a (történeti) kutatás különitene el egymástól tájakat. A táji tagolódás létrejöttében a területi munkamegosztás fontosságára helyezi a hangsúlyt. Ennek kétféle típusát különíti el: egyes - eltérö természeti adottságokkal rendelkezö, és ezzel összefüggően eltérő termelésü - területek kőzötti cserekapcsolatokat, illetve város és vonzáskörzete kapcsolatát. A két típus kưlönbsége nemcsak időrendi eltérést takar: az elsőben az eltérő adottságú, de hasonló társadalmi struktúrájú tájak kerulnek egymással érintkezésbe, a másodikban a város és vidéke eltérỏ társadalmi szerkezete is indukálja a munkamegosztás kialakulását és a kapcsolatokat (Tóth 1980). Miután a formális régiólehatárolások eredményeit kevésnek találja, a funkcionális lehatárolás mellett tör lándzsát. Azt vallja, hogy a formális régiólehatárolás gyakran prekoncepcióval dolgozik, a kutatók egy vagy néhány tényezőt vizsgálva homogénnek tüntetnek fel egy régiót, amikor az funkcionálisan több körzetre eshet szét. Hangsúlyozza azt is, hogy az összes tényezö kölcsönhatásrendszere csak a modern kor statisztikai viszonyai között vizsgálható. Definíciót is ad az ezen elvek figyelembevételével feltérképezendö történeti tájra: hosszú távon változatlan területi-ökonómiai-szociális egység, melyet a gazdaság más egységektől elkülönülö funkcionális rendszere jellemez, s ehhez a társa- 
dalmi fogyasztás speciális rendszere is kapcsolódik (Tóth 1980, 240-241). Tóth Tibor definíciója a funkcionális régiók földrajzi meghatározására emlékeztet, azonban nem ad arra választ, konkrétan hogyan is, milyen módszerekkel lehetne lehatárolni ezeket a tájakat.

Faragó Tamás összegyüjtötte a történelem és a rokontudományok régiólehatárolási eszköztárát. Miután hangsúlyozza a regionális történeti kutatások szükségességét, maga is kísérletet tesz arra, hogy a történeti táj fogalmát értelmezze. A történeti táj a legkisebb rendszerként vizsgálható egység, amelyet öt alrendszer összjátéka rajzol ki (gazdasági, társadalmi, kulturális, infrastrukturális, természeti), rugalmas, önszabályozó rendszer; rơvid távon az állandóság, hosszabb távon a változás jellemzi. A történeti tájak lehetséges vizsgálati módszerei közül legjobban használhatónak azt tartja, ha a különböző alrendszereket leírjuk, és ebből állítjuk össze a rendszerként értelmezett tájat, azaz, ha a különböző téregységek határai egybeesnek, történeti tájat rajzolnak ki (Faragó 1984, 15-16). Az ő módszere megpróbálja ötvözni a formális és a funkcionális régió-lehatárolás elönyeit.

Megállapíthatjuk azt, hogy a történészek, etnográfusok fogalmai nem azonosak a geográfusok terminusaival, bár gyakran ugyanazokat a jelenségeket írják le. Pl. a táj fogalmát társadalomföldrajzi egységekre is használják, holott a földrajz ezt a természetföldrajzi egységek számára tartja fenn.

Feltételezhetjük azt is, hogy a nemzetgazdaság egységesülésével, az államigazgatás kiépülésével, a tömegkultúra elterjedésével a régiók, körzetek közötti különbségek folyamatosan halványodnak, az önálló arculatú és struktúrájú régiók feloldódnak az országokban. (Tehát éppen korszakunkban történne ez a folyamat.) Angliai kutatások viszont éppen a régiók erösödó elkülönülését igazolják a XIX. sz. második felében. Úgy tünt, hogy a vasutak kiépullésével felszámolódik a regionális piac, a közlekedési feltártság növekedésével csökkennek a területi különbségek; azonban a meginduló iparosodás éppen nem csökkentette, hanem növelte a regionális eltéréseket (természetesen egy régión belul a falu-város különbségeket is). Megerősödött a regionális identitás (ennek szembetủnő megnyilvánulási formája a regionális regények elszaporodása), megerösödtek a helyi döntéshozás, hatalom igényei is. Mindez a regionalizáció megjelenéséhez vezetett, a helyi hatalom tudatosan törekedett a döntések decentralizálására, a régió sok tekintetben informális rendszerének formalizálására (Butlin 1990, 5-10). A gazdaság területi különbségeinek teljes felszámolódásával nem számolhatunk. Nemes Nagy József hosszú idősorokra végzett számításai azt igazolták, hogy egy új gazdasági struktúra (vagy innováció) megjelenésekor a tér kitüntetett pontjain indul meg a növekedés, ami gyors polarizálódáshoz vezet, ezt követi egy lassú kiegyenlítődési periódus; a folyamat itt nem áll meg, egy új jelenség felbukkanása ismét polarizálódást indít el (Nemes Nagy 1990, 133-136). Ez a vizsgálat is igazolja, hogy a területi különbségek hosszú távon fennmaradnak, időröl-időre átalakulnak, de jelenlétủkkel a történelem során mindig számolhatunk.

Egy bizonyos: adott gazdasági, társadalmi térszerkezet fennállása nem örök, állandó, és általában lassú a változás. Adott régió léte is csak meghatározott időtartamra 
igazolható. A régiók életkora az öket létrehozó (tér)folyamatok tartósságától fúgg. Amíg ezek a teret generáló folyamatok kis változásokkal tovább élnek, addig áll fenn egyensúly, addig marad fenn a kialakult régió (Kósa 1998, 31). Kósa László etnográfus megállapitása nemcsak a történeti-néprajzi egységekre igaz. Térfolyamatok döntő megváltozása területi újjárendeződést eredményez, régiók határának megváltozásához, esetleg teljesen új régiók kialakulásához vezet. A megváltozott térszervező erők legtöbbször új helyeket tüntetnek ki, változnak az átrendezödő, keletkezö régiók centrumai is. Találunk azonban példát arra is, hogy egy település (a már megszilárdult településhálózat tehetetlensége folytán) befolyásolja az új térszervezö folyamatok irányát, vagy ezek a folyamatok ismét ezt a pontot találják a legkedvezőbbnek (Kerekes 1923,1). Jelen vizsgálatunk is azt célozza, hogy milyen és mekkora volt az új folyamatok ereje a Kisalföldön, mennyire rendezték át a korábbi kapcsolatokat, mennyire változtatták meg magát a régiót.

\section{A Kisalföld mint régió}

Azt a kérdést kell elsőként megválaszolnunk, hogy a mi vizsgálatunk mit tekint Kisalföldnek, és az mennyiben tekinthetö önálló régiónak. Első megközelítésben a Kisalfơldön természetfơldrajzi egységet érthetünk, amely a Duna jobb és bal partján helyezkedik el, területén ma Magyarország, Szlovákia és Ausztria osztozik. Medenceterület, felszínét elsósorban a Duna és nagyobb mellékfolyói, a Vág, a Rába és a Marcal formálták, mai domborzata a pleiszthocénban és holocénban alakult ki. Jelentős antropogén beavatkozás a táj életébe a koraújkorban, újkorban következett be a vízrendezések hatására, a korábbi árterek nagy részét ármentesítették, jelentős mocsárterületet csapoltak le. A fattyíágakkal sürün átszött, mocsaras rétekkel, ligeterdőkkel változatos táj egyveretübb lett, területének nagy része szántófôldi müvelés alá került. A szántóföldi müvelést a kedvezö (sok tekintetben az Alföldnél jóval kedvezőbb) éghajlati- és talajadottságok segítették elb. Gyakorlatilag a gabonafélék, a kapásnövények, a takarmánynövények minden fajtája jó körülmények között termeszthető. A Kisalföld természetföldrajzi egysége kistáji tagoltsága ellenére nyilvánvaló (Góczán 1998, 302-305), a Kisalföld (természetfơldrajzi) tájvizsgálatának ez a megfelelő kerete. A természetfơldrajzi Kisalfỏld azonban (már) nem tökéletes alapja egy társadalomföldrajzi egységnek. Az Árpád-kori Magyarország régiókra való tagolását Frisnyák Sándor kísérelte meg. Véleménye szerint a táji specializáció megindulása a XIII. sz.-ra tehetô. Az ő vizsgálatában a Kisalföld egész területe alkot egy régiót, a hozzá tartozó vásárvárosokkal egyủtt. Ez is bizonyítja, hogy ebben az időszakban a természetföldrajzi viszonyok messzemenően meghatározták a társadalmi tér alakulását is (Frisnyák 1996, 122-123). Azonban annak, hogy a Kisalföld táj tényleges funkcionális régióvá alakuljon, volt egy komoly akadálya. A Duna vonala megnehezítette az átkelöforgalmat, nemcsak maga a folyó, hanem a mellette szélesen elterülő árterei is. Ez a markáns vonal két egységre osztja, osztotta a tájat a múltban is, s nem csak a jelen országhatár idején. Az északi fele Pozsony piackörzetéhez, közigazgatási vonzáskörzetéhez tartozott, a nem 
természetföldrajzi értelemben vett Felvidék része („Duna bal part”). A kereskedelmi forgalom iránya kelet-nyugati volt, mindkét térség Bécs és Alsó-Ausztria felé vonzódott, egymással gyengébbek voltak a kapcsolatok (sokáig hiányoztak az összekötő vasúti és közúti hidak is). A vasúthálózatuk is önállóra formálódott ki, nagyon sokáig semmiféle vasúti összeköttetés vagy állandó híd nem volt a két térség között (Erdösi 1996, 227; 230; 232). A Kisalföld területének kettéosztottságát a közigazgatási beosztás és a statisztika is követte, a XVIII-XIX. sz. közigazgatási átalakítás-kísérletei mindig erre a két részre bontották a területet. II. József tízkerületes felosztása és a Bach-korszak ötkerületes beosztása is figyelembe veszi ezt a határvonalat. A Bach-korszak kerületi székhelyei, Pozsony és Sopron is tükrözik, hogy eltérő vonzódású területekröl van szó (Hajdú 1996, 215; 218). A II. József korabeli és a Bach korszak (területileg eltérő, s egyik esetben sem csak kisalföldi területeket magában foglaló) kerületeinek eltérỏek voltak a központjai is. Az elöbbié Györ, az utóbbié Sopron (Szörényiné Kukorelli 1998, 55). A két hasonló régió elkülönüléséröl a modernkori statisztika is tudomást vesz: Dunántúl és Duna bal part megkülönböztetéssel választotta szét a (már) csak természetföldrajzilag egységes területet. Formálisan a két régió társadalomföldrajzi képe is hasonló, azonban funkcionálisan nem képeztek egységet.

Jelen tanulmány vizsgálódási területe a Kisalföldnek csak a Duna jobb parti egységére terjed ki, a továbbiakban - az egyszerüség kedvéért - ezt nevezziuk (mint a magyar geográfia általában) Kisalfôldnek. Társadalomföldrajzi régió képződése történeti folyamat, általában jellegzetes idöponthoz, időszakhoz köthetjük ennek megindulását. Esetünkben a döntő mozzanatnak a török hódoltság korát tekinthetjük. A három részre szakadt Magyarország területei más országokhoz kerültek, az elkülönült országrészek arculata más irányba fejlödött, megváltoztak kapcsolatrendszereik is, a bontakozó belső munkamegosztás szálait szétzilálta a hódítás (Gyimesi 1975, 139). A török hódoltság határa elvágta a területet az ország középső részétöl, kapcsolatai a birodalom központjával, Béccsel erösődtek meg. Helyzete a birodalom szempontjából felértékelödött: stratégiai vonal húzódott a peremén, Bécs és Alsó-Ausztria élelmiszerellátásában fokozódott a szerepe (Beluszky 1995, 26-27). A török jelenlét nemcsak a gazdasági kapcsolatokat változtatta meg, hanem átalakította pl. az agrártermelés módját és a településviszonyokat is. A Dunántúl déli részén vagy pl. Fejér és Komárom megyében jelentös számban pusztultak a falvak (erre területünkön kevés példát találunk), a városok fejlődése egészen más pályára lépett, mint régiónkban. Itt ún. praesidionalis mezővárosok (pl. Devecser, Körmend, Sárvár, Kapuvár) alakultak ki, olyan települések, ahol a vár mellett jelentős katonaréteg élt (gyakran családostul). Ez a hajdúszabadsággal felruházott lakosság a korai, feudális keretek közötti polgárosulás egyik jellegzetes képviselöje volt. Ilyen típusú településeket nem találunk a Dunától északra, ezek elsősorban a Dunántúl végvidékeire jellemzöek (Rúzsás 1968, 23-25). A térség kaputáj-jellegú terület volt már a kőzépkor elejétől fogva, s ez a jellege tovább erősödött a XVIII. sz.-ban. A legfontosabb kereskedelmi utak, elsősorban a Duna vízi útja itt vezettek nyugat felé a Duna-parti városok fejlődését elősegitve. Egy fontos szárazföldi út a Fertő tavat és 
mocsarait délrỏl, a Soproni-hegységet északról kerülve Sopron érintésével jutott Ausztriába. Itt halad el az Alpok előterében évszázadok óta használt fontos É-D-i útvonal, a Borostyánkő-út utódja is (Beluszky 1995, 23-24). Vas megye területéről is kisebb-nagyobb jelentőségủ utak vezettek Ausztriába, pl. Grazba. Ezen utak fontossága a középkor vége óta folyamatosan növekedett. Magyarország mezógazdasági exportjának döntő része (elsősorban marha és bor) és a növekvő iparcikkbehozatal is ezeken az utakon bonyolódott. Ez természetesen a városok, mezővárosok kereskedelmének élénkülésével is járt. A régió a XVIII. sz.-tól Bécs ellátó körzete volt, amely az ország legdinamikusabban fejlődö területévé vált (elsősorban gabona- és gyapjúexportja révén), olyan területté, amelyet elöször értek el az újitások, az ország „legmodernebb" térsége lett (Frisnyák 1992, 67). Ez volt az a terület a Dunántúlon, amely először kapcsolódott be az európai gazdasági rendszerbe az árutermelése révén (Benda 1995, 55). Fejlettségét, modernségét sokféle tényezővel mérhetjük. Az ország mezövárosokkal legsürübben túzdelt területe már a XVIII. sz. elejétől a Zala megyétől Trencsén megyéig húzódó sáv volt, a XIX. sz. elejére ezen belül Vas és Sopron megyék még erősödtek is. A városhálózat nemcsak a legsủrübb volt, hanem a város jogi és funkcionális típusait tekintve a leggazdagabb is. Ebben a térségben vált először általánossá a háromnyomásos gazdálkodás már a XVIIIXIX. sz. fordulóján (Timaffy 1988, 28), ill. a vetésforgó alkalmazása is a XIX. sz. második harmadára (Kósa 1998, 192). A népi kultúra átalakulása, polgárosulása is a modernség egyik fokméröje lehet. A térségben a viselet, a tánc- és népdalkultúra, az étkezési szokások változásai is mind ezt jelzik. Az országtól, a Dunántúl tơbbi részétől való elkülönülést más jelenségek is jelzik. A terulet az ország egyik legsürübben lakott része volt a XVIII. sz. végén (Rétvári 1977, 48.), s ez a helyzet csak az Alföld dinamikus népességnövekedése miatt változott meg a XIX. sz. során. Birtokszerkezetét tekintve is külön egységnek tekinthetó a térség. Rúzsás Lajos a nagybirtok súlya alapján 3 zónára osztja a Dunántúlt, melyben Vas, Moson, Sopron, Győr vármegyék területe alkot önálló egységet. Ez az a zóna, ahol a nagybirtok és a kisbirtok aránya kiegyenlített ( $K o ́ s a 1998,188$ ).

Társadalomföldrajzi régiónk határai más szempontból sem egyeznek a természetföldrajzi Kisalfơld határaival. Vizsgálatunkban nem választhatjuk le a vele szomszédos, egységet alkotó hegy- és dombvidéki területet, akkor sem, ha nem tartoznak a Kisalfơld tájhoz. Az általunk vizsgált régióhoz hozzátartoznak ezek a területek, városok; térkapcsolatok kötőtték össze őket, a városok funkcionális vonzáskörzete ezekre a teruletekre mindkét irányban kölcsönösen kiterjedt. Célszerủ a vizsgálati terület határát a közigazgatási egységekhez igazítanunk, mert ilyen egységekben áll rendelkezésünkre a statisztikai anyag jó része, ugyanakkor jogos is, mert éppen ez az a korszak, amikor a közigazgatási funkciók, hatáskörök nagyban befolyásolják a térszerkezet alakulását. Vizsgálatunk így a következỏ teruletekre terjed ki: Győr, Moson, Sopron, Vas vármegyék és Veszprém vármegye devecseri és pápai járása. Komárom vármegye tertlete kimarad ebből a területbỏl, Komárom városa már a Csallóközben fekszik, a komáromi járás is jórészt itt terül el. Komárom vármegye gesztesi járása ugyan magában foglal kisalfơldi telepulléseket is, de ezek a települé- 
sek eltérnek régiónk településeitől: a hódoltság idejében elpusztásodott területen nagyhatárú falvak fekszenek, amelyek birtokszerkezetére a nagybirtok jelenléte jellemző, és más a települések térkapcsolatainak iránya is.

\section{A Kisalföld a XIX. sz. elsö felében}

Vizsgált területünk tehát a formális régiólehatárolás alapján mindenképpen térszerkezeti egységként érte el a modern kor küszöbét. Első kérdésünk: hogyan alakultak a térkapcsolatok ebben az időszakban. Létezik egy régi keletủ, Thünenre visszanyúló elképzelés a területi kapcsolatok kialakulására. A történeti fejlödésnek a városok kialakulása elötti korszakában (közelebbről meg nem határozott, tájanként eltérőnek feltételezett időszak) a falvak (gazdasági) életét a nagyfokú autarkia jellemezte. Azonban a kibontakozó területi munkamegosztás széttöri az autarkiát, egyrészt a falvak közötti táji specializáció révén, másrészt a városokba koncentrálódó, körzetének igényeit kielégitő (kézmü)ipar és kereskedelem révén (Mendöl 1963, 375). Megjegyzendő, hogy a táji specializációt mindenképpen sziukségessé tette a természeti erőforrásokkal való specifikus ellátottság. Akkor is, ha a tájak közötti termékcsere kis mértékủ volt, mindig létezett, mivel egyes kedvezö körülmények között elöállított termékböl felesleggel rendelkeztek. Ezek a termékek azonban nemcsak a szomszédos tájak között cserélhettek gazdát, hanem távol fekvök között is, a piacos helyek pedig gyakran csak szervezöi voltak a cserének, nem pedig felvevöi (Tóth 1980, 232). Teljes körủ falusi autarkiával nem nagyon számolhatunk tehát. Régiónkban azonban részlegessel sem, bizonyítottan már a középkor óta. Láttuk, hogy a régió létrejöttében (elkülönülésében) mekkora szerepe volt a modernizálódásnak, az európai piacba való bekapcsolódásnak. Ha pontos felmérések állnának rendelkezésünkre, valószínüleg már a XVIII. sz.-ban sem találnánk olyan zárt gazdaságú falvakat, amelyek az ország egyes hegyvidéki területein még a XIX. sz.-ban is léteztek. Olyan táji specializációt, amelyet Andrásfalvy leír, minden bizonnyal szintén csak nyomokban találnánk a XVIII. sz.-ban. Ebben a térségben a központok szerepe már meghatározó, nincsenek a városoktól érintetlen tájak, falvak; az árutermelés és a pénzhasználat már széles körú. Itt a térszerkezeti változások már a központok helyének megváltozását jelentik, a központok és körzetük közötti kapcsolatok átalakulását.

A térség gazdasági kapcsolataiban legfontosabbnak a mezőgazdasági termékek forgalmát tekintjük. Magyarország a XX. sz. elejéig, derekáig agrárország volt, a nemzeti jövedelem nagy részét ez a szektor állította elö, a népesség nagy része is itt dolgozott. A magyar gazdaság dinamikája is ehhez az ágazathoz kötödik, a mezögazdasági konjunktúrák tették lehetővé a lakosság vagyonosodását, többféle értelemben is. Nemcsak az agrárnépességét, hanem az agrárnépesség vásárlóerejétöl fủggő (kézmú)iparosokét, az agrártermékek forgalmazásából (vagy a külföldi iparcikkek eladásából (természetesen elsősorban az agráriumból élő fogyasztónak továbbadó) élö kereskedőkét is. Nem véletlen az, amit Gyimesi Sándor megállapít: a XVIII. sz. végétől az agrárvárosok mutatnak fel dinamikát, egy általa több időpontra 
azonos módszerek alapján összeállított rangsorban a szabad királyi városok jelentöségvesztésével szemben a mezóvárosok nyernek teret (Gyimesi 1975, 163-166). Megállapítását kiegészítenénk azzal, hogy nem a városok jogi különbözősége a lényeges, hanem az, hogyan tudnak bekapcsolódni az agrárgazdaságba, akár mint termelök, akár mint a termékek kőzvetítői. Az agrárszektor dinamikáját igazolja az is, hogy a korszakban folyamatos a szabad királyi városi kézmüipar hanyatlása, mikőzben az iparosok aránya különösen az 1830-as, 1840-es években gyorsan növekszik. A jelenség magyarázata a falusi, mezővárosi kézműipar fejlódésében rejlik, melynek fejlödése pedig a falusi árutermelés fellendülésével, a vásárlóerő nővekedésével hozható összefüggésbe. Mindez a városi ipar szerepének jelentős meggyengúléséhez vezet. Gyimesi Sándor eljut ahhoz a megállapításhoz is, hogy a XIX. sz. első felében a kézmüipar már nem városképző erỏ (Gyimesi 1975, 175). A városok fejlödésének sokkal fontosabb tényezöje volt az agrárkonjunktúrába való bekapcsolódás. Így vizsgálatunkban is kitüntetett szerepet kell kapnia az agrártermékek forgalmának, a kézműipar térszervezó szerepét pedig csekélyebbnek kell tekintenünk.

\section{A térszervezés formái és központjai}

A falusi termékek külkereskedelmét a Kisalföldön két eltérỏ szervezet végezte: a városok, mezővárosok kereskedői, illetve az uradalmak (uradalmi kőzpontok: sokszor maguk is mezővárosokhoz kapcsolódnak). Elöször az uradalmakról essék szó. A XVI-XVII. sz.-ban erösödik meg az uradalmak helyzete, szerepe, ök azok, akik árutermelésükkel elöszőr kapcsolódnak be a nyugati piacok forgalmába. Kezdetben csak a saját termékeikkel kereskednek, később az uradalmakhoz tartozó falvak jobbágygazdaságaiban elóállított terményeket is felvásárolták, elsősorban az uradalom alkalmazásában álló zsidó terménykereskedők révén. A jellegzetes árucikk ebben az időszakban az élő́llat (elsösorban marha), s később a gyapjú volt. Míg a jobbágygazdaságok bekapcsolódhattak a belkereskedelembe elsősorban a városi piacok ellátása révén, a külkereskedelmet ekkor szinte kizárólag az uradalmak szervezték. A XVIII. sz. elsö feléig az áruk exportjának haszna a nagybirtokosoknál csapódik le. Ez természetesen gátolta a városok árutermelését, kereskedelmét (Rúzsás-Szũcs 1966, 38). Arról már megemlékeztunk, hogy az uradalom gazdasági, gazdaságszervezési funkciója mellett bíráskodási, igazgatási szerepet is ellátott. Az uradalom olyan térszervezö erö lett, amely meghatározta az emberek és áruk mozgását az uradalom területén. Ilyen uradalmi központ volt a Kisalfơldön pl. Pápa, Rohonc, Németújvár, Szalónak, Pinkafö, Sárvár, Kapuvár, Körmend, Kismarton, Magyaróvár, Jánosháza. Ezen telepủlések fejlödését, központi funkcióinak kiépủlését uradalmi központ voltuk nagyban befolyásolta, néhányan közülük késöbb, amikor uradalmi központ szerepük megszünt, vagy ennek jelentősége elhalványodott, az új funkciók közül is számosat magukhoz tudtak ragadni. A településhálózat lassan változó rendszer, sajátságos tehetetlensége van, amikor a dinamikahordozó elem már jelentőségét veszti, hatása még sokáig jelentkezik. Egyes funkciók meg- 
léte más funkciókat is odavonz, ezek térszervezö ereje új táplálója a fejlődésnek (Mendöl 1963, 377). A térszervezödésnek - mint láttuk - eltérö hierarchiaszintjei vannak, léteznek olyan kapcsolatok, amelyek a szükebb körzetre terjednek ki, vannak, amelyeknek hatása regionális léptékben érvényesül, és vannak régión túlnyúló, országos léptékủ jelenségek. Az uradalmak térszervező ereje az első kategóriába tartozik, hatóköre az uradalom falvain nem terjedt túl, ha az uradalmi központ ennél jelentősebb szerepre tett szert (pl. Pápa), akkor ez nem uradalmi kőzpont jellegéböl következett, hanem más jelenségek hozták létre.

$\mathrm{Az}$ uradalmak fontossága a térszervezés legalsó szintjén a XVIII. sz. második felében kezdett gyengülni. Az 1754-es vámrendelet kedvezötlenül érintette a határszéli uradalmak külkereskedelmét, ugyanakkor az igazgatási központ jellegük már nem volt olyan erös, hogy központi funkciójuk megmaradjon. Ebben az időben állandósult a megyegyủlések székhelye, egyre fontosabbá vált az állami, egyházi (pl. püspökség) igazgatási szervezet, erősödött a városok kulturális funkciója is (iskolák stb.). Mindez a városok szerepének bővüléséhez vezetett (Bácskai 1995, 60-62). Látjuk majd, hogy az uradalmi központok szerepét folyamatosan átveszik a kisvárosok azon fejlỏdés során, ahogy a polgári igazgatás intézményei felváltják a feudális intézményeket, ahogy a feudális gazdaságszervezés helyét átveszi a szabad verseny.

Másodikként a városok szerepköréról emlékezünk meg. A jogi felosztás kétféle várostípust ismert: a szabad királyi városok (civitas) és a mezővárosok (oppidum) csoportját. Hangsúlyozzuk, hogy ez jogi különbségtétel, az elhatárolás pusztán a városok kiváltságait tükrözi, nem pedig gazdasági szerkezetüket. Mezővárosi jogállás sokféle lehetett, közös jellemzőjük, hogy földesưri fennhatóság alatt állottak, és néhány kiváltsággal rendelkeztek (vásártartási jog, valamilyen önkormányzati, bíráskodási autonómia). Az uradalmi központok többsége is élvezte a mezövárosi kiváltság elönyeit, de mint láttuk, térszervezö szerepük jó része nem ebből fakadt, mezővárosi privilégiumaik inkább csak hangsúlyosabbá tették ezt a szerepet. A szabad királyi városok közvetlenül a királyi fórumok alá tartoztak (tehát a megyeszervezet hatálya sem terjedt ki rájuk), és országgyülési képviselettel bírtak. A mezőváros nem egyenlỏ az agrárvárossal, egy részüknél a kereskedelmi, ipari tevékenység meghatározó volt, a szabad királyi városok jó része pedig speciális mezögazdaságából (bortermelés) élt. A két városcsoport egyike sem fedi azt a definíciót, amit a településföldrajz a városokra alkotott: a területi munkamegosztás azon eleme, amely központi funkciókat lát el, kevésbé mindennapi szükségleteket kielégítő szolgáltatásokat tömörít (Mendöl 1963, 26). A városok vizsgálatát tehát nem szükíthetjük egyik csoportra sem, hanem a funkcionális városfogalom megvilágításában nekünk kell ezen csoportokból a valódi városokat elkülönítenünk.

Térségünkben öt szabad királyi város volt ebben a korszakban, Györ, Sopron, Kismarton, Ruszt és Kőszeg. Az utóbbi négy város gazdaságában a legnagyobb szerepet a bortẹmelés és a kereskedelem játszotta. Kismarton és Ruszt külföldön értékesitette borát, elsősorban Ausztriában (Rúzsás 1963, 20-21). Térszervezö funkciója egyiküknek sem jelentős, nem vettek részt sem az egyéb agrártermékek 
forgalmazásában, sem a külföldi cikkek elosztásában. Vidékük terményeinek, alacsony lakosságszámuk következtében nem lettek jelentős fogyasztói, kézmüipari tevékenységük jelentéktelen. Borkereskedelmüket az 1754-es vámrendelet kedvezőtlenül érintette, ezután már nem tudtak új funkciókat magukhoz kapcsolni (Beluszky 1999, 78). Ezen két város közül Kismarton az, amely csekély térszervezö szereppel bírt. Köszeg és Sopron gazdasági életében is jelentös szerepe volt a bortermelésnek és kereskedelemnek (Rúzsás 1963, 15; 18), azonban ezek a városok más funkciókat is betöltöttek, mindkét település az Alpokat a Kisalföldtöl elválasztó vásárvonalon fekszik (Frisnyák 1992, 51). Mindkét városban éltek olyan kereskedök, akik a külföldi iparcikkek behozatalával és forgalmazásával foglalkoztak, ezenkívül Sopron bekapcsolódott az agrártermékek forgalmába is, kiváltképp Alsó-Ausztria és Bécs piacainak ellátásába. A soproni kereskedök elsösorban a régióban elöállított mezögazdasági termékek forgalmát szervezték. Sopron közlekedési helyzete jó, a Fertö tó és mocsarai ill. a Soproni-hegység jelölték ki a Ny-K irányú út irányát, amely itt kereszteződött a már régi időktől használt É-D irányú úttal (Borostyánkö-út). Sopron megyeszékhely szerepe és kulturális központ jellege is erősítette térszervezö funkcióit (Matejka 1959, 454). Sopron (kisebb mértékben Kőszeg) szerepe kettős volt. Egyrészt a város piackörzetéhez tartozó települések termékeinek forgalmát bonyolitotta, másrészt egy nagyobb léptékủ (más hierarchiaszintü) kereskedelembe is bekapcsolódott, ami túlmutatott szük (város)körzetének keretén: más területek forgalmát is szervezte, hatóköre az egész Kisalföldre, esetenként a Dunántúlra, és más országrészekre is kiterjedt. Kulturális központ szerepe is túlmutat a régión: evangélikus líceuma, teológiai főiskolája, jogakadémiája, bencés gimnáziuma a régión kivuullre is éreztették hatásukat.

Györ a Rába és a Marcal torkolatában kitünő közlekedésföldrajzi helyzetét kamatoztatta. A szárazföldi utak számára jó és elkerülhetetlen átkelőhely: a Rába és a Marcal mocsarai itt összeszúkülnek, lehetővé téve a K-Ny irányú forgalmat. A Fehérvár felól érkezỏ utat a Sokoró akadálya tereli északi irányba, amely szintén itt éri el a Rábát. A város leginkább a Mosoni-Duna vízi útjának előnyeit élvezte, ezzel a lehetőséggel a nagyobb kisalföldi városok közül egyedül rendelkezett (Kalmár 1923, 61-63). Ez a vízi út adja Győr specialitását: ez a város nemcsak szủkebb városi vonzáskörzetének központja (és elsősorban nem az), szerepe teljesen más. Györ a XIX. sz. elejéig kisalföldi gabonát gyüjt, és azt közvetíti Bécs és AlsóAusztria felé (Rúzsás 1964). Már ez is regionális léptékủ szerepére, kapcsolataira, térszervezö erejére utal. A XVIII. sz.-ban kibontakozó agrár-árutermelés lassan túlnyúlt - az ebbe először bekapcsolódó - Kisalfơld határain, a közlekedésileg feltárt területeken terjeszkedett tovább az Alföldön. A terjeszkedésnek különösen gyors időszaka volt a napóleoni háborúk gabona-konjunktúrája (Beluszky 1999). Ez a közlekedés a vízi forgalmat jelenti, elsősorban ilyen módon lehetett nagyobb mennyiségủ, szállitásra érzékeny árut forgalmazni. Amíg a marha volt a legfontosabb kiviteli cikk, ennek szállítása a szárazföldi utakat követte, ezen utak menti városok profitáltak ebböl a kereskedelemböl. Ilyen fontos útvonal volt pl. az ún. „Mészárosok útja”, amely Budáról Székesfehérváron át vezetett Györ irányába, 
onnan tovább Ausztriába. Ebbe a forgalomba olyan városok is hatékonyan be tudtak kapcsolódni, , amelyek nélkülözték a vízi út előnyeit (mint pl. Sopron). A XIX. sz. elejére gyökeresen megváltoztak a feltételek. Az új árucikk és annak szállítási módja, közlekedési feltételhez való kötöttsége átrajzolták a távolsági (országos léptékü) kereskedelem térszerkezetét, új településeket tüntettek ki a megváltozott gazdasági feltételek. A Kisalföldön a gabonakereskedelem haszonélvezöje először Pápa, Moson és Magyaróvár, majd a gőzhajózás megindulásával az 1830-as évektöl egyértelmúen Györ lett. A három ágra szakadó Duna ágai közül a Mosoni-Duna volt a hajózás számára a legkedvezöbb, de ez is csak kisebb hajókkal volt járható a szabályozást, kotrást megelōzően. A Bécs felé tartó szállítmányokat Gönyủnél, Győrnél át kellett rakni kisebb hajókra, majd Magyaróváron szekérre (Kövér 1982). Az Öreg-Duna kotrása után elöször Moson és Magyaróvár szorulnak ki ebböl a kereskedelemből, Győr gabonakereskedelme azonban más szerencsés tényezők kővetkeztében megmarad (Rúzsás 1964). E három (igazából kettö) város, ha rövid időre és eltérő mértékben is, de országos térszervező szerepet, jelentőséget töltött be, kereskedöik bácskai, bánáti gabona forgalmazásával foglalkoztak. Györ szerepe hangsúlyosabb, kereskedői tényleges szervező szerepet töltenek be, Moson és Magyaróvár sokkal alárendeltebb, a városok fontosságát igazából az átrakás szükségessége biztosítja. A Moson és Magyaróvár városkettősből az utóbbi rendelkezik adminisztratív és oktatási szerepkörökkel. Magyaróvár uradalmi központ, Moson vármegye székhelye, a XVIII. sz. végétől pedig gazdasági akadémiának is helyet ad. Gyór kulturális központi szerepe is túlmutat a városi piac szervezte vonzáskörzetén (ami viszont majdnem egybeesik adminisztratív körzetével, Győr vármegyével): katolikus püspöki székhely, a bencés gimnázium, a jogakadémia, a teológiai főiskola - regionális, esetenként régión túlnyúló szerepkört betöltỏ intézmények.

Pápa esetében is felrajzolhatjuk ezen kettős, hármas hierarchiaszintü térszerkezetet. Pápa uradalmi központ jellege mellett fontos mezőváros; sok iparos él a Bakony és a Kisalföld vásárvonalán fekvő városban, az uradalom árnyékában és védelme alatt nagyszámú zsidó kereskedó telepedik meg, akik bekapcsolódnak a terménykereskedelembe (1848-ig a legtöbb szabad királyi város kitiltja falai közül a polgárok komoly konkurenciảjaként jelentkezỏ zsidókat, megtelepedésük elsősorban az uradalmak központjaiban és más mezővárosokban lehetséges [a Kisalföldőn így pl. Rohoncon vagy Pápán].) Ez a sajátosság is magyarázza, hogy ebben a korszakban a mezővárosok fejlődése, vagyonosodása sok esetben gyorsabb, mint a szabad királyi városoké. Pápa kiveszi a részét a marhakereskedelemből, majd a kisalfóldi gabonakereskedelembỏl, melynek hatásköre messze a régión túlra is kiterjed (igaz, a Bakony falvai felé érvényesülö hatása a kisebb mértékú árutermelés miatt a forgalom volumenében nem olyan jelentös) (Matejka 1959; Rúzsás 1964). Pápa református központként tölt be régión túlnyúló funkciókat. Itt van pl. a Dunántúli Egyházkerület kollégiuma (ami nemcsak középiskola, hanem teológiai föiskola is).

Korszakunkban kezdödik Szombathely fejlödésének az a felíveló szakasza, amely zenitjét a polgári korszakban éri el. A város fontos és forgalmas közlekedési útvonalakon fekszik, amelyek már a római időszakban jelentős települést fejlesztettek. 
Az Alpok elő̉terében levő É-D irányú útvonal, a Borostyánkő-út itt találkozik azzal a K-Ny irányú úttal, amely Graz felöl a Rába-völgyben éri el Magyarországot, és amelyet a Rába mocsarai kényszerítenek É-i kitéröre. Erröl a pontról Ausztria felé még tơbb kisebb jelentőségü út vezet. Ezenkivül Szombathely megyéjẻnek centrumában is fekszik, bár a megye központjának szerepét a középkorban Vasvár töltơtte be (Kerekes 1923). Szombathely mint mezöváros a XVIII. sz.-ig csupán városkörnyékének piacközpontja volt, ennél nagyobb térszervező hatást nem tudott kialakitani (Rúzsás 1964). Egészen a koraújkorig a városok egyik meghatározó funkciója volt a védelmi szerepkör betöltése. Ezt a védelmi szerepkört kihasználva iparosok, kereskedök telepedtek meg a vár oltalma alatt, vagy ritkábban az ő jelenlétük tette szulkségessé erödítmény emelését (Mendöl 1963). Ez régiónkban a török hódoltság szomszédságában különösen fontos volt. Ennek a funkciónak a kisalföldi városok is eleget tettek, minden városnak vagy országos (esetenként birodalmi) jelentőségủ végvára volt (pl. Győr), vagy kisebb erössége, mint a praesidionalis mezővárosok erődítményei. Szombathely nem fekszik jól védhetö helyen, számottevő erősség nem volt a városban. A városhoz vezető utak mentén viszont számos mezöváros és vár található (Sárvár, Vasvár, Körmend, Kőszeg, Rohonc, Szalónak, Németújvár, Léka). Gyakorlatilag ezeken a telepuléseken szétszórva érvényesultek Szombathely fekvésének elönyei, az utak csomópontjától kicsit távolabb. Ezen telepưlések részint mint uradalmi központok, részint mint kisvárosok töltöttek be térszervező szerepet. Közullük, mint láttuk, elsősorban Köszegnek volt a régióra is kiterjedö hatókơre. Amint a védelmi funkció jelentőségét veszti (a kuruc harcok múltával), úgy tudja fokozatosan érvényesíteni Szombathely a fekvéséből származó előnyőket; úgy alakul át a térszerkezet, idomulva a közlekedési adottságokhoz. Szombathely elönyeinek érvényesulését kezdetben még gátolja Köszeg versenye, azonban Köszegnél hiányoznak azok az adminisztrativ funkciók, amelyek Szombathely fejlődésében éppen a XVIII. sz.-tól egyre jelentösebbek lesznek. Vas vármegye székhelye, Mária Terézia uralkodása óta katolikus puspökség központja, ez azonban ebben az időszakban még kevés a dinamikához, az igazi (gyorsaságában a Kisalfôldön egyedulálló) fejlődés a polgári korszakban veszi kezdetét (Kerekes 1923).

\section{Városhierarchia-kísérletek a feudális korszakra}

Történtek kísérletek a magyarországi városok koraújkori, újkori hierarchiajának megállapítására. Gyimesi Sándor vizsgálatának eredménye igazából nem hierarchia, hanem csupán városrangsor, pontmódszer segitségével rangsorolta a feudalizmuskori városállományt, és kísérletet tett arra is, hogy a városiasság alsó ertékét ezen pontmódszer segítségével meghatározza. Négy tényezőtt vett figyelembe: a telepulések népességét, iparosaik számát, igazgatási funkcioiikat és kulturális szerepkőruket (Gyimesi 1975). Vizsgálatát ugyanolyan szempontok és ugyanolyan típusú adatok alapján 1715-re és 1828-ra is elvégezte (1. táblázat).

Bár pl. az 1715-ös lakosságszám-becslésének pontossága megkérdőjelezhető, és pontmódszerével kapcsolatban más problémák is felmerülnek (egyes intézmények 
súlyozása, a kereskedelmi tevékenység nagyságának gyenge reprezentációja stb. (Bácskai-Nagy 1984), mégis, mivel jól jelzi a változást, érdemesnek tartjuk bemutatni a kisalföldi, (e módszerrel) városnak tekintett települések rangsorát.

\section{TÁBLÁZAT}

A kisalföldi városok helyzete Gyimesi Sándor 1715-re és 1828-ra vonatkozó városrangsorában

(Position of Cities of Kisalfold in the City Hierarchy in 1715 and 1828 Made by Gyimesi)

\begin{tabular}{|c|c|c|c|c|c|c|}
\hline & Település 1715 & $\begin{array}{l}\text { Rang- } \\
\text { szám }\end{array}$ & $\begin{array}{l}\text { Pont- } \\
\text { szám- } \\
\text { érték }\end{array}$ & Település 1828 & $\begin{array}{l}\text { Rang- } \\
\text { szám }\end{array}$ & $\begin{array}{l}\text { Pont- } \\
\text { szám- } \\
\text { érték }\end{array}$ \\
\hline 1. & Gyór & 3. & 13,3 & Györ & 4. & 10,4 \\
\hline 2. & Pápa & 13. & 6,2 & Sopron & 13. & 7,9 \\
\hline 3. & Sopron & 17. & 5,5 & Szombathely & 18. & 7,0 \\
\hline 4. & Köszeg & 29. & 3,2 & Pápa & 20. & 6,5 \\
\hline 5. & Nezsider & 36. & 2,1 & Kőszeg & 37. & 2,7 \\
\hline 6. & Szombathely & 36. & 2,1 & Magyaróvár & 48. & 1,5 \\
\hline 7. & Magyaróvár & 42. & 1,4 & & & \\
\hline 8. & Rohonc & 46. & 1,0 & & & \\
\hline
\end{tabular}

Forrás: Gyimesi 1975.

Vizsgálata Magyarország területén 1715-ben 74, 1828-ban pedig kereken 100 települést talált városiasnak, oly módon, hogy ugyanazt a rangszámot egyezỏ pontszám esetén több település is megkaphatta. 1715-ös vizsgálatának utolsó rangszáma a 46, az 1828-as vizsgálatának pedig az 52 (Gyimesi 1975, 262-266). Szembetünő a két idöpont között Szombathely és Köszeg helycseréje. Bár ebbe belejátszik az is, hogy Gyimesi módszerében túlreprezentáltnak tünik az igazgatási szerepkör súlya, az elmozdulás valós folyamatokat tükröz. Szombathelyen már a polgári időszakot megelőzően sokkal nagyobb volt a „modern” ágazatok súlya, mint Kőszegen (Beluszky 1999). Pápa is pozíciót veszít Sopronnal szemben: Pápán is hiányoznak azok az adminisztratív funkciók, amelyek jelentösége a korszakban fokozatosan növekszik, és amelyek Sopron súlyát emelik.

Bácskai Vera és Nagy Lajos is kísérletet tettek az 1828-as idöpontban a városhierarchia vizsgálatára. Az 1828. évi országos összeírás külön pontban kérdezett rá a falvak eladó- és vevőhelyéül szolgáló piacokra. Ez alapján, ha nem is tökéletesen, le lehet határolni egyes piacközpontok kereskedelmi vonzáskörzeteit. A forrást nemcsak térkép felrajzolására lehet használni, az összeírás még számtalan adatot tartalmaz a piacközpontokra és a falvakra is. Az adatokat három faktorba csoportosították, a faktoranalizisek eredményébỏl pedig egy mutatót hoztak létre; a változók között legnagyobb súllyal a népességszámra vonatkozó adatok szerepelnek, városrangsoruk pedig elsősorban a kereskedelmi vonzáskörzet népességét reprezentálja (Bácskai-Nagy 1984, 100-102). Megjegyezzük, hogy vitatható a faktoranalizisek eredményeinek egy mutatóvá való alakítása, az egyes faktorokban elért rangszámok súlyozatlan összesitése, mindezen fenntartások után közöljük ezt a rangsort is, 
hangsúlyozva, hogy elsősorban a kereskedelmi funkciókat, azon belül is a város és piackörzete egységét tükrözi. Vizsgálatuk Magyarország területén 138 piacfunkciót betöltő települést talált (Bácskai-Nagy 1984, 122-124). A településeket piacközponti funkcióik eróssége alapján öt kategóriába sorolták. A központi funkciók érvényesülése alapján Sopron és Györ az igen erös (I.), Pápa, Szombathely, Körmend és Köszeg az erős (II.), Moson-Magyaróvár (vizsgálatukban a két mezóváros összevontan szerepel), Kismarton, Nezsider a közepes (III.), Kiscell pedig a gyenge (IV.) kategóriába került (2. táblázat). Ez a vizsgálat és értékelése arra koncentrál, hogy a városok fejlődésében-fejlettségében nem a távolsági vagy külkereskedelmi szerepkör a lényeges (mint korábban), hanem a vonzáskörzet ellátásában, szervezésében megnyilvánuló központi szerepkör (Benda 1995). Azonban vizsgálatuk és interpretációjuk szempontjai nem azonosak az általunk használt szempontokkal, igy ezeket a besorolásokat nem tudtuk beilleszteni munkánkba.

\section{TÁBLÁZAT}

A kisalföldi városok helyzete a

Bácskai Vera-Nagy Lajos által készitett városrangsorban, 1828 (Position of Cities of Kisalföld in the City Hierarchy in 1828 Made by Bácskai Vera and Nagy Lajos)

\begin{tabular}{|c|l|c|c|}
\hline & \multicolumn{1}{|c|}{ Település 1828 } & Rangszám & Pontszámérték \\
\hline 1. & Sopron & 3. & 46,5 \\
\hline 2. & Györ & 8. & 64,0 \\
\hline 3. & Pápa & 21. & 109,5 \\
\hline 4. & Szombathely & 29. & 123,0 \\
\hline 5. & Körmend & 40. & 156,5 \\
\hline 6. & Köszeg & 41. & 158,0 \\
\hline 7. & Moson-M.óvár & 51. & 181,5 \\
\hline 8. & Kismarton & 74. & 224,5 \\
\hline 9. & Nezsider & 76. & 228,5 \\
\hline 10. & Kiscell & 122. & 303,0 \\
\hline
\end{tabular}

Forrás: Bácskai--Nagy 1984, 122-124.

Jelen vizsgálatunk alapján a Kisalföld városait a központok térszervező szerepének fényében három csoportba sorolhatjuk be. Akár hierarchia-tagolásnak is fölfoghatjuk ezt a három szintet. Az elsó csoportba Győr kerülne első helyen, és más-más szempontok alapján Sopron és Moson-Magyaróvár. Ezek a települések olyan helyzetben vannak, hogy térszervezö tevékenységük, kapcsolataik túlnyúlnak a régió határain, más országrészeken is érvényesítik hatásukat. A második kategória települései: Pápa, Szombathely, Köszeg, olyan városok, amelyeknek kapcsolatai elsösorban a régió területén érvényesülnek. A harmadik kategória a kisvárosok és uradalmi központok világa. Ez a településcsoport a legheterogénebb, mintegy háromtucatnyi település, amelyek a térszervezés legalsó szintjét képviselik: kizárólag saját környékük számára gyakorolnak központi funkciókat. Egyesek hatásterülete nagy, mint például Körmendé, a Batthyány-uradalom központjáé; a kisebb uradalmak 
Tér és Társadalom, 13. 1999. 4. 77-106. p.

központjai (pl. Szany mint mezőváros, a györi püspökség néhány faluból álló keszői uradalmának központja) csekély körzetre gyakorolnak hatást, azonban a vonzáskörzet eltérö nagysága nem jelent eltérő hierarchiaszintet.

\section{A térszerkezet változásai a polgári időszakban}

Tanulmányunk bevezetésében röviden összefoglaltuk, milyen új hatások érik régiónk térszerkezetét a vizsgált időszakban. Most ezen hatások elemzésére térünk ki. Mendöl Tibor a városi vonzáskörzetek kialakulásának (átalakulásának) folyamatát történeti léptékben is megpróbálta összefoglalni. A közlekedés lassúsága volt az a korlátozó tényező, amely határt szabott a városi vonzáskörzetek növekedésének. Ezen időszakban a kicsi városok és kicsi vonzáskörzetek jellemezték a teret. A vonzáskörzetek nem minden esetben értek össze, várostalan területek ékelödtek közéjük, ahol nagyfokú autarkia jellemezte a falvak életét. Ezek a foltok a közlekedés fejlődésével felszámolódtak, a városi vonzáskörök már nemcsak érintkeztek, hanem egymás rovására is terjeszkedtek. A városállomány (hálózat?) megrostálódott, a városok egy része feleslegessé vált, a szükséges funkciókat jobb adottságú települések nagyobb hatékonysággal elégítették ki. Teljesen nem szünt meg a kisebb városok létjogosultsága sem, bizonyos funkciókat megtartottak, másokat a nagyobb települések átvettek tölük. Kialakult a vonzáskörzetek és funkciók hierarchikus rendje (Mendöl 1963). Mi úgy találtuk, hogy a Kisalföldön ez a hierarchikus rend már a XVIII. sz.-ban kialakult, valószínüleg már azóta létezik, amióta a régió bekapcsolódott az árutermelésbe és a távolsági forgalmazásba. Most azonban gyökeresen megváltoznak a térszervezódés feltételei, s nemcsak a közlekedés átalakulása miatt.

\section{A polgári igazgatås hatásai}

A polgári korszakban az uradalmak igazgatási, igazság-szolgáltatási szerepe végleg megszünt. Az alsó fokú bíráskodás és közigazgatás színhelyei a járási (szolgabírósági) székhelyek lettek. A járási székhely szerepkör betöltése éles határt húzott a legalacsonyabb fokú központok között. Például Sopron megyében 40, Vas megyében 39 mezővárost találhatott a XIX. sz. közepének utazója (Kósa 1998, 185). Természetesen ezek egy része semmilyen központi szerepet nem töltött be, városias arculatról vagy városi társadalomról sem beszélhetünk többségüknél, de nagy hányaduk bírt valamilyen térszervezó szereppel (esetek többségében mint uradalmi kőzpont). A járási székhelyek ezeket a szórt szerepköröket egyesítették, így azok a tényezők, amelyek e településeket táplálták, most a járási székhelyen egyesülhettek. Az uradalmakhoz hasonló gazdaságszervező szerepet természetesen a járások nem folytattak, így ennek térszervezó ereje nem ruházódott át. Ugyanakkor megváltozott a kapcsolattartás intenzitása, egyre több szolgáltatást kellett igénybe venniưk a falusiaknak a bürokrácia és a szakszerủség szélesedésével, és egyre több szolgáltatást használhattak az igények növekedésével. A falu-város kapcsolatok súrüsődését 
elősegitette és gyorsította a közlekedési lehetőségek javulása. Az eleve városhiányos térségekben bizonyult különősen gyorsnak az igazgatási központok fejlödése (Beluszky 1999). Térségünkben a következö települések voltak járási székhelyek: Moson vármegyében: Magyaróvár, Nezsider és Rajka; Győr vármegyében: Györ, Györszentmárton (ma Pannonhalma) és Tét; Sopron vármegyében: Csepreg, Csorna, Közép- majd Felsőpulya, Kapuvár, Kismarton, Nagymarton és Sopron, Vas vármegyében: Felsőőr, Kiscell, Körmend, Kőszeg, Muraszombat, Németújvár, Sárvár, Szentgotthárd, Szombathely és Vasvár; Veszprém vármegye érintett területein pedig Devecser és Pápa. Természetesen voltak olyan járási székhelyek, amelyek az adminisztratív funkciókon kívül semmilyen más kapcsolatot nem tudtak környékükkel kiépíteni, ez esetben városi szerepkörröl bajosan beszélhetünk (Beluszky 1999). Térségünkben -ilyen járási székhelynek tekinthetjük Rajkát, Felsöpulyát, Csepreget, Győrszentmártont és Németújvárt.

A megyegyülések székhelyeinek, mint láttuk, már a XVIII. sz. dereka óta növekszik adminisztratív funkciója. Ez a polgári igazgatás korában már a járási intézmények fölötti igazgatási, bíráskodási szintet is jelent. A megyeszékhelyeken már számottevő tisztviselöréteg telepedik meg, $\mathrm{s}$ az állami hivatalok holdudvarában felduzzad a középrétegek létszáma. Térségünkben egyetlen olyan települést találunk, amely csak intézményeiben tölti be a megyeszékhely funkciót, polgárság vagy városi élet nem nött fel ehhez a szerephez: ez Magyaróvár (Beluszky 1999).

Rövid életủ intermezzónak bizonyult a megyerendszer fólszámolásának kísérlete a Bach-korszakban. Sopron adminisztratív térszervező szerepe messzi a régión túlra kiterjedt: Veszprém, Zala, Somogy, Tolna és Baranya vármegyék is a soproni központ igazgatása alá kerultek (Szörényiné Kukorelli 1998). Mindez az összes megyeszékhely adminisztratív térszervezó erejének koncentrációját jelentette volna. Gyakorlatilag tartományi jellegü területegységeket szerveztek az országból, így a kઠzpontok igazgatási, bíráskodási szerepe hihetetlenül felduzzadt, nagyszámú katonaságot vezényeltek a városba, számos új intézmény telepedett meg ekkor. (Például az ebben az időben megszervezett állami postaszervezet központjai is a kerületi székhelyekhez kötődtek, s ma is Sopronban találjuk a Postaigazgatóságot.) Ez tartós változást nem hozhatott, az új közigazgatási felosztás szük tíz esztendőt élt meg, és amikor megszünt, Sopront százával hagyták el az alig pár éve letelepedett morva, cseh és osztrák tisztviselők (Rétvári 1967).

Ide kívánkozna a kulturális intézmények hatásának értékelése. Ez is része a faluváros kapcsolatok megváltozásának. A városok egyre több kulturális szolgáltatást nyújtanak, amelyeket a falusiak mind gyakrabban vesznek igénybe. Ezen szolgáltatások közőtt a legfontosabb az oktatás, a középiskolák jelenléte. Léteznek kulturális vonzáskörzetek is, ezek feltérképezése külön kutatást igényel.

A polgári viszonyok áttekinthető (és centralizált) közigazgatást kívántak, ezért megszüntették a heterogén mezővárosi jogállást és egységesítették a városok kőrét. A tơrvényhatósági jogú városok a volt szabad királyi városok közül kerültek ki; ezek számát először bővítették, majd 1876-ban erőteljesen megrostálták, és azok, amelyek nem érték el a 12000 fös lélekszámot, automatikusan kiestek. Ezen tele- 
pülések a megyei igazgatással kerültek egy szintre, míg a városok másik csoportja, a rendezett tanácsú városok köre a járási igazgatás alól került ki, de a megye jogköre kiterjedt rá. Ez a csoport sem volt túl tág: elsősorban a törvényhatósági jogból kiszorult volt szabad királyi városok, a püspöki városok, a polgárvárosok, tehát a mezövárosok elitje került bele. A városok rendi megkötöttségének feloldásával vált lehetővé a városok közötti szabad verseny, ami nagyon sok település fejlődésének új irányt szabott. A két városkategóriában 1910-ben összesen 138 várost találunk (Hajdú 1996, 218-219; Gyáni-Kövér 1998, 52-53).

A Kisalföldön törvényhatósági jogú város Györ és Sopron lett, míg Szombathely, Pápa, Köszeg, Kismarton és Ruszt tartoztak a rendezett tanácsú városok közé. Mint látjuk, e városfelosztás elvei sem tettek eleget a funkcionális városszemlélet követelményeinek, hiszen pl. térségünkben olyan különböző települések, mint Ruszt és Szombathely egyaránt városi címet viseltek; Moson vármegye viszont egyike lett az ország azon kevés vármegyéjének, ahol az I. világháborúig nem volt város. Ezen városokban a járási illetve megyei intézményekkel azonos funkciójú és súlyú hivatalok müködtek, amelyek térszervező hatása azonban (érthető okokból) nem jelentkezik.

\section{A gazdasági változások hatásai}

A dualizmus kori gazdaság legszembetủnőbb átalakulása a gyorsuló iparosodás. De tudnunk kell azt is, hogy Magyarország továbbra is agrárország maradt, a nemzeti jövedelem növekedésének legfontosabb forrása a mezögazdaság korszerüsödése, illetve növekvő piacra termelése, kivitele (Beluszky 1999, 132-133). A mezögazdasági termékek feldolgozása az iparosodás egyik meghatározó mozgatója volt, kisebb jelentőséggel, de elősegítette ezt a mezőgazdaság gépigénye is. A mezőgazdaság piacra termelését a kiviteli lehetőségek szükülésével a belsỏ fogyasztás növekedése ösztönözhette is, azaz a szekunder és tercier foglalkozású lakosság arányának megugrása, tehát az iparosodás fölgyorsulása (Kövér 1982). A vasúthálózat kiépülésének irányait, gyorsaságát is elsősorban a mezőgazdasági termékek, kitüntetetten a gabona szállitásának igényei szabták meg (Frisnyák 1992, 102). Régiónkban ezen időszakban lett a területi fejlődés egyik meghatározó tényezöje az iparosodás. A század végére a Kisalföld területe az ország egyik legiparosodottabb térségévé vált, iparszerkezetében a könnyứ- és dz élelmiszeripar dominált, de a nehézipar is képviseltette magát (Béluszky 1999, 138). A századfordulón megjelenik egy egészen ủj térformáló folyamat, a városi ipari üzemekbe történő ingázás.

\section{A Kisalföld és a vasutak}

A vasútvonalak hatása a területi pályák, kapcsolatok átrendezödésére, a települések fejlödésére némiképpen túlértékeltnek vagy félreismertnek tünik. A vasutak hatását legtöbbször úgy értékelik, hogy egyes települések (a csomópontok) virágzását elindították és táplálták, azokon a településeken pedig, amelyeket a vasút elkerưlt, néhány évtizedre megállt az élet. Ez a kép leegyszerúsít egy sokkal összetettebb folyamatot. Ugyanis nemcsak a közlekedési pályák áthelyeződéséről és új 
térhálózat kialakulásáról van szó, és elsősorban nem erröl. A vasút dinamizálja az egész gazdasági életet, nem egyes pontokat alakít át, hanem az egész teret átformálja. Nem csupán azért fejlődnek a vasúti csomópontok dinamikusan, mert egy új hálózatnak lettek a kituntetett pontjai, hanem azért mert azok a területek, ahonnan vasútvonalaik befutnak, bekapcsolódnak a modern, árutermelő gazdaságba. Nem összemérhető a jelenség azzal a korábbi átrendeződéssel, amit leírtunk: amikor a marha- ill. borkereskedelem központjai elvesztik térszervezésük erejét az új kiviteli termék, a gabona térhódításával. A gabonakereskedelem központjai csak részben estek egybe a korábbi kủlkereskedelmet szervező városokkal; ekkor az új termelési struktúra új térszerkezet kialakulását vonta maga után, ez magyarázta Győr gyors elöretörését a XIX. sz. elején, és Sopron viszonylagos stagnálását. A vasút megjelenésével a közlekedés felgyorsul, a városi vonzásterület új területeket tud elérni, a vasút térfeltáró szerepe azonban nem merül ki ennyiben. A vasút új lehetöségeket nyit, megélénkíti a vidékek gazdaságát, a csomópontok dinamikája nem a térpályák áthelyeződéséből fakad, hanem abból, hogy dinamizálódó területek központjai lesznek, nem a korábbi fejlesztő erők csoportosulnak csupán át, hanem új erök kapcsolódhatnak be a térfejlödésbe (Mendöl 1963).

A vasút országos piacot teremt, a korábbi archaikus táji munkamegosztás nyomait is felszámolja. A vasutak településfejlesztő hatása kétségtelen, de a vasutak vonalvezetését a meglévö gazdasági térszerkezet és térpályák is befolyásolták. A vasút is épít várost, de a város is épít vasutat; a megyeszékhelyek, amelyek ambicionálták a vasútfejlesztést, a megyei piacot saját magukhoz tudták szervezni. Ilyen megyeszékhely volt pl. Szombathely. De nem igaz az, hogy Szombathely csupán a vasútjai miatt került fölénybe Köszeggel szemben. Szombathely a XIX. sz. elején a tömegáruk kereskedelmével, gabona-, állat-, épületfa-, építőanyag és mindenféle termény kereskedelmével foglalkozott, míg Köszeget a bortermelés és -kereskedelem, céhes kézmüipar és az importáruk szétosztása jellemezték, azaz nem a XIX. sz. húzóágazatai (Beluszky 1999). Szombathelyen láthatjuk azt legjobban, hogy a vasutak nyomvonalai a régi szárazföldi utakat követik, szó sincsen a térpályák áthelyeződéséröl, hanem a dinamizálódásról. Szombathely már akkor Vas megye középpontjában volt, amikor vasutaknak még se híre, se hamva nem volt, a fejlödés során helyzetét jobban ki tudta használni, ill. mivel Vas megye gazdasága is élénkült, a központi jelleg is több gyümölcsöt hozott (Kerekes 1923).

Külön kell bontanunk a fövonal-hálózat és mellékvonal-hálózat kiépülésének idöpontját és hatását is (először a térszerkezet legfelső hierarchiaszintje alakult át, kisebb hatással az alacsonyabb szintekre). A fövonal-hálózat kiépülése a távolsági kereskedelmet dinamizálta, alakította át, míg a helyi gazdasági élénkülés a mellékvonalak kiépülése után következik be (Erdősi 1991). Mindezek figyelembevételével vesszük számba a vasútvonalak kiépülése nyomán bekövetkező változásokat.

A vasutak kiépülése néhány évtized alatt történt meg, eltérö idöpontban ért el településeket, ezért a térszerkezet is gyorsan változhatott ebben az idöszakban. A legnagyobb változást a korábban föként a folyóvízhez kötött gabonaszállítás szenvedte el. Moson és Magyaróvár, mint láttuk már az 1830-as években elvesztette 
korábbi szerepét a gabonakereskedelemben. 1855-ben nyílott meg a (Bécs-)BruckGyör-Újszőny vasútvonal. A Györig vízi úton szállított gabonát most már nem kisebb hajókra rakják át, hanem vasútra, $s$ úgy szállitják tovább Bécs felé (Rúzsás 1964, 8-9). Györ egyelöre az átalakuló szállítási pályákon is kitüntetett pont maradt. Az 1850-es évek a város kereskedelmének fénykorát jelentik, új kikötő épül, mintegy másfél száz raktárépület, 1845-ben megépül a Dunántúl legnagyobb malma, új bankok, pénzintézetek nyílnak, és kiépülnek a külvárosok (Matejka 1959, 454). Györ országos szerepköre azonban leáldozóban van. A pesti gabonakereskedök az alföldi gabona vízi és vasúti szállitásában egyaránt átveszik a szervezỏ szerepet. A pesti malmok által megörölt gabona ill. az őröletlen termény vasúton, vagy az öreg Duna teljes kotrása után, vízi úton, Györ kikapcsolásával közvetlenül kerül a piacra (Kövér 1982). Györ virágzása nem a legalsó, vagy második térszervezö hierarchiaszint kihasználásából fakadt, hanem a legfelsőéből, az országosból. A regionális, vonzáskörzete piacának megszervezésének feladatát elhanyagolta, $\mathrm{s}$ ez a város dinamikájának megtörésében bosszulja meg magát az 1870-es évek elejére. (Egybeesik ez a gabona-értékesítés egyik mélypontjával, a gazdasági válság időszakával is.) Az 1884-ben Újszőny és Budapest között megvalósult közvetlen vasúti összeköttetés már csak lezárja ezt a folyamatot; Györ elveszíti régión túlnyúló szerepének jelentős részét (Rúzsás 1964). Ebben az idöszakban kárpótolja magát Györ a regionális kereskedelem megszervezésével. 1872-ben megépül a Győr-PápaKiscell-Szombathely(-Graz) vasútvonal, majd 1876-ban a Győr-Sopron közötti összeköttetés is. Ekkor ragadja el Győr Pápától a regionális gabonakereskedelem központi szerepét (gyakorlatilag a közép-dunántúli gabona elött nyit piaci lehetöséget ez a vasút), $s$ az új vasútvonalak Bécs kikerülésével új piaci irányokat is jelentenek (reményt a tengeri szállításra is). Azonban Györ már nem lesz nemzetközi gabonakereskedelmi központ, hiába tudja eljuttatni gabonáját Triesztbe, majd Fiumébe. A magasabb hierarchiaszint helyett kénytelen beérni a jóval alacsonyabbal. Az európai piacokon megjelenö olcsó orosz és amerikai gabona versenye lehetetlenné teszi a magyar agrártermékeknek a Monarchia határain túli értékesítését, a gabonaexportban Budapest versenye amúgy is elnyom minden konkurenciát. Az 1896-ban Veszprém felé megépülö vicinális már a város közvetlen vonzáskörzetének piacszervezési igényét jelenti. A századforduló után a városi piackörzetet, méretéből is adódóan nagyon hatékonyan tudja szervezni Györ. 1910-ben az egész Kisalföldön Györ megyében a legalacsonyabb a hetivásárokat tartó települések száma és a vásárok gyakorisága, míg az országhatár fele haladva, rohamosan növekszik a vásárok száma (Princz 1934).

$\mathrm{Az}$ átalakulás érzékenyen érinti Pápát is. Pápa regionális gabonakereskedelme és térszervezése súlyosan károsodik az 1872-es vasútépítéssel. Gyakorlatilag szervező szerepét Győr veszi át a térségben, Pápa népességnövekedése megáll, a város dinamikája megszünik. A Dunántúl egykor második legnépesebb városa a hanyatlás jeleit mutatja (Matejka 1959). Hanyatlásában śzerepet játszik az is, hogy Pápán (némi gyáripara ellenére) igen erös a kézmüipar szerepe, ez az ágazat pedig a múlt század utolsó évtizedeiben egyre mélyebb válságba süllyed. 1896-ban mellékvonal 
épül Csorna, 1902-ben pedig Bánhida felé, ettöl kezdve a település elsősorban városi vonzáskörzetének kereskedelmét fogja szervezni, jelentősége ennél távolabbra is kisugárzik, de az egykori regionális térszervező szerep már a múlté (Majdán 1995; Rúzsás 1964).

$\mathrm{Az}$ a város, amelynek közvetítő kereskedelme a vasútépítések hatására nemhogy gyengül, hanem erősödik, az Szombathely. Szombathely kitünó földrajzi helyzetében már rég predesztinált a regionális térszervezö szerepre, ez a szárazföldi utak világában kevésbé tudott megvalósulni, most a vasutak lehetővé teszik ezen szerep betöltését. Korszakunk elején rövid idöre csökken térszervezó hatékonysága: a Bruck-Györ vasútvonal megnyitása elragadja regionális vonzáskörzetének északi részét Györ javára (Rúzsás 1964, 16). 1865-ben megépül a Sopron-SzombathelyNagykanizsa vasúti fövonal, amely a Bécs felé irányuló kereskedelmet dinamizálja, majd a tenger felé is kapcsolatot nyit. A regionális szerepkőr további erősödésével jár az 1872-es Graz-Szombathely-Györ vasútvonal megnyitása is. A szerepkör növekedése itt is együtt jár a város lakosságának felduzzadásával, a külvárosok kiépülésével (Kerekes 1923, 19). A mellékvonalak a város közvetlen vonzáskörzetének kiterjesztését illetve növelését szolgálják a környékbeli kisvárosi központok rovására. A város megyeszékhely, ennek a hatalomnak az elönyeit élvezi akkor is, amikor a kiépülő megyei vicinális-hálózatot Szombathely központúra formálja (Beluszky 1999). A megyei közgyülés határozata szerint a megyei költségvetésböl és helyi alapokból támogatják a székvárosba befutó vonalak építését (Majdán 1995). 1883-ban megépull a Szombathely-Köszeg (ezt a vonalat később Sopronig meghosszabbítják), 1891-ben a Szombathely-Porpác-Hegyeshalom-Pozsony, 1894ben a Szombathely-Rum, 1898-ban a Szombathely-Pinkafö mellékvonal (Rúzsás 1964, 16). Gyakorlatilag Vas megye egyik részéböl a másikba csak Szombathelyen keresztül lehetett utazni. Szombathely megszilárdította regionális szervezö szerepét, s messze kiterjesztette városi vonzáskörzetét.

Sopron a dunántúli városok közül elsőként kapott vasútvonalat, Bécsújhely-Bécs irányába, még 1847-ben, s ezt a vonalat bővítették 1865-ben Szombathely-Nagykanizsa felé. 1871-ben épült meg a györi vonal, ami Ebenfurthnál csatlakozott az ausztriai vonalhálózathoz. Ezzel vált teljessé a fövonalak megépítése: Sopron regionális szervezö szerepe nem növekedett ugyan, de nem is csökkent, országos térszervező szerepről pedig már a XIX. sz. derekától nem beszélhetünk. Mellékvonal itt is a városkörnyéki vonzáskörzet kielégítésére épült Köszeg felé. A megye vasúthálózata korántsem olyan monocentrikus, mint Vasban, vagy Györben: Fertöszentmiklós, Wulkapordány, Csorna önálló vasúti csomópontok.

A korábbi regionális térszervezö kőzpont, Köszeg jókora szerepvesztést szenvedett el a polgári korszakban, csupán városkörnyéke szervezó szerepét tudta betölteni. A vasúti fővonalak is elkerülik az országos és regionális szempontból elhanyagolható települést, csupán 1883-ban jut Szombathely irányából vicinálishoz. Köszeg városi vonzáskörzetét szervezỏ településsé degradálódik (Rúzsás 1963).

Azon települések, amelyek járási székhellyel bírtak, és ehhez vasútállomás, vagy csomópont is társult, kiterjesztették vonzáskörzetüket a környék kisebb központjai 
rovására. Pl. Csorna, amely piacközponti funkciót betöltỏ mezőváros volt, állomására öt irányból érkeztek vonatok, a vicinálisok megjelenésekor kimutathatóan megugrott a lakosságszám, a település vonzáskörzete is szélesedni tudott. Persze a vasúti csomópont nem mindig hozta magával a fejlỏdést, sokszor a társadalom befogadó készsége, nyitottsága az újításokra, sokkal jelentősebb tényező volt ennél. Körmend a XIX. sz. elején Szombathelyhez hasonló népességú mezőváros volt, a távoli környékét is átfogó vonzáskörzettel bírt, jelentős uradalmi központ volt. Már 1872-ben volt vasútállomása is, a századvégen pedig csomóponttá vált. A település vezető társadalmi csoportját a szélsőségesen konzervatív világlátású kézmúvesek adták. Nem fogadták el az állami gimnázium odatelepitését, mondván, hogy nincs erre igény, és elzárkóztak minden újitás elöl. A város korábbi vonzáskörzetébe élesen belemetszett északról a gyorsan növekvő Szombathely; nyugatról pedig az a Szentgotthárd, amelynek lakosságszáma alig volt harmada Körmendének, viszont a település vezetésében invenciózus értelmiségiek, tisztviselök ültek: ök támogatták az állami gimnázium letelepedését, az állami dohánygyár ellen sem emeltek kifogást, számos modern ipari üzem telepedett meg a városban (kaszagyár, óragyár, selyemgyár). Az apró központba egyetlen vasútvonalán is számtalan ingázó érkezett, a település lakossága messze nem tudta kielégíteni az üzemek munkaeröszükségletét, vagy az iskola diáklétszámát. Szentgotthárd innovatív társadalma olyan előnyt jelentett, amelyet Körmend múltja, tekintélye és (ami fontosabb) vasútjai ellenére sem tudott pótolni.

Van olyan település, amely meghatározó mértékben a vasútnak köszönheti gyors gyarapodását: Kiscell, illetve 1903-tól Celldömölk. A korábbi búcsújáróhelyen a vasúti csomópont-jelleg és a járási székhely az alapja a gyarapodásnak, a kisvárosi társadalom meghatározó rétegét is a vasutasok és tisztviselők alkotják (Majdán 1995; Beluszky 1999). A kedvező vasúti helyzet elösegíti a központi települések gyors iparosodását, a központi szerep markánssá válását is. Olyan település, mint Sárvár vasútja(i) segítségével tesz szert ipari üzemekre (köztük a legjelentösebb a cukorgyár), s válik élénk életủ és funkciójú kisvárossá. Répcelakon viszont, amely vicinálisok metszéspontjában fekszik még kimutatható népességgyarapodást sem okozott a csomópont-jelleg (Majdán 1995, 194).

Összefoglalva a vasutak hatásáról mondottakat: láthattuk azt, hogy az összes olyan település, amely országos térszervezö erövel rendelkezett a vasutak megjelenése elött, elveszti ezt a szerepkörét. A hanyatlás általános: Györ regionális szervező erejủvé csúszik vissza, Kőszeg regionális hatóköre már korábban meggyengült, Pápáé pedig az 1870-es években válik erőtlenné. Moson és Magyaróvár térszervezö ereje még megyéjük keretét sem tölti ki, csupán városi körzetükre koncentrálódik. Sopron megtartja regionális szerepkörét, miközben Szombathely folyamatosan erősödve épít ki ilyen regionális hatókört. A század elején négy város gyakorolt ilyen térszervezö szerepet, Györ, Sopron, Pápa és kisebb mértékben Köszeg. Most három település, három megyeszékhely: Györ, Sopron és Szombathely tölt be hasonló szerepkört. Más szempontú vizsgálat is már csak e három városnak tulajdonít regionális szerepkört (Beluszky 1999). A térszervezés legalsó szintjén a vasutak 
hatása szintúgy differenciáló. Az az egykor bármilyen központi funkciót betöltő telepulés, amelyik sem vasúti csomópont jelleggel, sem járási székhely funkcióval nem rendelkezik elveszíti térszervező szerepének maradékát is. Ez a törvényszerüség persze nem minden esetben igaz, és föként visszafelé nem igaz. Porpác, Hegyfalu, Bük vagy Répcelak hiába fekszenek vasutak metszéspontjánál, ettöl még nem töltenek be térszervező szerepet.

A régió a koraújkortól kezdve az ország centrumának szomszédságában, annak közvetlen közelében helyezkedett el, a modernizációban elöl járt. 1867-tel áthelyezödik a hatalmi centrum, és lassan a gazdasági súlypont is elmozdul az új föváros és annak ipari, szolgáltató potenciálja felé. A régió nem lesz periférikus helyzetủ, de látványos fejlődése már nem folytatódik; városai kiszorulnak a korábbi országos térszervező szerepből. A dualizmuskori fejlödés elsősorban a fövárosra és az Alföldre koncentrálódott, a Kisalföld változásai nem annyira szembetủnỏek (Benda 1995,55 ). Átalakult és modernizálódott a mezőgazdaság, a régió nagyobb települései gyorsan iparosodtak; a terménykereskedelemben összegyült töke átáramlott a gyáriparba (Rúzsás 1964). A városok népességnövekedése azonban vontatott volt (kivéve Szombathely), a jelentősebb városok zöme lassan növekedett, vagy inkább stagnált (Köszeg, Pápa, Sopron).

Budapest gyors növekedése térszervező erejének szélesedéséhez is vezetett. A tőkefelhalmozásban, pénzintézetek számában, ipari potenciálban, hatalmi dőntésekben olyan elképesztő fölényre tett szert, amellyel a térség városai a távolság ellenére sem tudtak versenyezni. Nem véletlen, hogy a gabonakereskedelem szervezése, amelyben a kisalfơldi városok élen jártak, teljesen Budapest kezébe kerül. Budapest országos térszervezb̋ szerepe a Dunántúlon nem enged élni vetélytársakat, gyakorlatilag az ország más részein sem (Rúzsás 1964), csak regionális centrumok nőhettek fel mögé. Egyértelmüen kijelölhető regionális centrum nem alakult ki a Kisalfôldön. Ezt a szerepet a három város egymás között felosztva látja el (Beluszky 1999). A kullönböző regionális léptékben előforduló intézmények e három város valamelyikében találhatók ( $\mathrm{pl}$. a postaigazgatóságot Sopronban, a MÁV igazgatóşágot Szombathelyen; az Osztrák-Magyar Bank fiókját Győrben találjuk).

Szót kell ejtenünk még az iparosodás okozta térszerkezeti átalakulásokról, hiszen a gyáripar kibontakozása alapvetően új térformáló jelenségekhez vezetett. A gyáripar megjelenésének hatását két aspektusra bonthatjuk: az egyik a városi vonzáskörzetek átalakulásában játszott szerep. A kapcsolatoknak új típusát alakította ki: a mindennapi ingázás, munkába járás. Bár ilyenre az iparosodás előtt is találunk példát, a falvak lakói napszámosként, szőlökapásként korábban is felkerestek lakóhelyưktől elkülönưlö telepưléseket, de ez a jelenség ekkor válik tőmegessé. Nem csak a nagyvárosokat érintette. Olyan kisebb, de iparral rendelkezö települések, mint Sárvár vagy Szentgotthárd már kialakitottak ilyen kapcsolatokat. Gyakran a közigazgatás is követte a változásokat, az agglomerálódó falvakat vagy a csak jogilag önálló telepưléseket a városhoz csatolták (ez tơrténik pl. Sárváron [Majdán 1995]). 


\section{Városhierarchia a polgári korszakban}

Láthattuk, hogy az 1870-es évek közigazgatási rendezésével megalkotott városi kritériumok sem tesznek eleget a funkcionális városszemléletnek. Ezért ismét a mai kutatók feldolgozásaihoz kell fordulnunk. T. Mérey Klára érdekes vizsgálatot végzett egy olyan kutatás keretében, amely a mai városhálózat történeti alakulását vizsgálta. Azok a városok, amelyek 1986-ban városi címet viseltek, de lakosságuk nem érte el a 30000 föt, képezték a dualizmuskori kisváros-vizsgálat alapját (T. Mérey $1995,49)$. Ez a „fejtetőre-állitott" vizsgálat bizonyos szempontokból nagyon termékeny lehet, de a mi kiindulási alapunk a korszak létező funkcionális városhálózata. Beluszky Pál 1900-ra készített el egy hierarchikus rangsort. Véleménye szerint a városok hierarchikus rangját a központi funkciót betöltő intézmények mennyisége és sokfélesége határozza meg. Vizsgálatában 75 intézmény előfordulását veszi figyelembe, súlyozatlanul, az intézmények kiválogatásánál elsődleges szempont volt, hogy nagyjából azonos számban kerüljenek be a különböző hierarchiaszintekhez kötödő intézmények. Természetesen nem ez a 75 intézmény generálja a teret, nem csak ezek alakítanak ki kapcsolatokat, hoznak létre eltérö szintủ vonzáskörzeteket, de jól reprezentálják a térkapcsolatok összességét. Beluszky 245 települést talált, amelyek a századfordulón valamilyen térszervező szerepet töltöttek be. Ezek közül a kisalföldieket mutatja be a 3. táblázat (Beluszky 1990).

\section{TÁBLÁZAT}

A kisalföldi városok helyzete a Beluszky Pál által az 1900-as évre készitett városhierarchiában

(The Position of Cities of Kisalfold in the City Hierarchy in 1900 Made by Beluszky Pál)

\begin{tabular}{|c|c|}
\hline Település & Rangszám \\
\hline Sopron & 15. \\
\hline Györ & 16. \\
\hline Szombathely & 18. \\
\hline Pápa & 85. \\
\hline Magyaróvár & 113. \\
\hline Szentgotthárd & 117. \\
\hline Köszeg & 137. \\
\hline Csorna & 182. \\
\hline Kapuvár & 188. \\
\hline Körmend & 192. \\
\hline Sárvár & 205. \\
\hline Devecser & 222. \\
\hline Nagymarton & 226. \\
\hline Kiscell & 235. \\
\hline Muraszombat & 238. \\
\hline Kismarton & 239. \\
\hline
\end{tabular}

Forrás: Beluszky 1990, 32-36. 
Táblázatunkban aláhúzással jelöltük a városi jogállással rendelkező településeket. Jól látható, hogy a jogállás nem tükrözi vissza a funkciót, Kismarton a táblázat alján foglal helyet, Ruszt pedig nem is szerepel. Sopron, Gyór és Szombathely a teljes értékủ megyeszékhelyek csoportjában gyakorlatilag egymás mellett foglalnak helyet, a regionális funkciókat a három város megosztva gyakorolja. A régió tőbbi városa nem került be a regionális központok közé. Láthatjuk azt is, hogy mekkora ür követi ezeket a városokat, Pápa messze leszakadva tỏlük a teljes értékü középvárosok kategóriájába került, és ennek a kategóriának az alján foglal helyet Magyaróvár és Szentgotthárd is. E városokat az általunk készitett besorolás csak a közvetlen vonzáskörzetét szervezỏ települések körébe sorolja, ezek közül a települések közül ez a három tökéletesen elláthatja ezt a funkciót, és bizonyos aspektusban ennél nagyobb szerepet is betölt. Köszeg, az egykori regionális szerepet ellátó központ, már csak részleges középváros, Szombathely mellett csak a helyi vonzáskörzete szervezésére képes. A többi város kisváros, amely rangra pl. Csorna, Kapuvár és Devecser joggal lehet büszke, de egy volt szabad királyi város, mint Kismarton már nem dicsekedhet vele. Érdekes Körmend és Szentgotthárd helyzete, melynek különlegeségéröl már megemlékeztünk. 1900-ban Körmend lakossága 6300 fölött van, míg Szentgotthárdé alig haladja meg a 2000-et. A népességnagyság és a térszervezö funkciók tehát ebben az esetben nincsenek arányban, a kettö között nincsen olyan szoros kapcsolat.

\section{Befejezés}

Tanulmányunk elején kitértünk arra, hogyan értelmezhető a „,Kisalfơld tơrténeti régió", és megpróbáltuk e fogalmakat kellőképpen megvilágítani. Tanulmányunk fö irányát az a törekvés jellemezte, hogy bemutassuk a különböző (elsősorban gazdasági) hatások nyomán időben hogyan változott meg a régió térszerkezete. A települések és vonzáskörzetek hierarchikus rendjét hármas tagolásban ábrázoltuk: a városi vonzáskörzet, a regionális és az országos szint szempontjából. Részletesebb vizsgálat természetesen finomabb beosztást hozhat, de úgy érzzük e három szint megfelel a térszerkezet legfontosabb tagolásának.

\section{Jegyzet}

'Ez úton szeretnék kőszőnetet mondani Beluszky Pálnak, illetve Nemes Nagy Józsefnek és Benda Gyulának, akik a tanulmány elkészitése során nagy segítségemre voltak.

\section{Irodalom}

Andrásfalvy B. (1980) Néprajzi csoport, kistáj és régió. - Népi kultưra - népi társadalom. XI-XII. 39-58. o. Bácskai V.-Nagy L. (1984) Piackörzetek, piacközpontok és városok Magyarországon l828-ban. Budapest, Akadémiai Kiadó.

Bácskai V. (1995) Dunántúl városhálózata a XVIII. században. A Dunántúl szolgálatában. Elõadások Rúzsás Lajos emlékének. - Horváth Gy. (szerk.), Pécs, MTA RKK.

Beluszky P. (1990) A polgárosodás tơrékeny váza - Városhálózatunk a századfordulón (Városhierarchia - vázlat, tényképekkel). - Tér és Társadalom. 3-4. 13-56. o. 
Beluszky P. (1995) A régió elhatárolása, torténelmi kialakulása: A Bécs-Pozsony-Gyôr régió együttmũködési lehetőségei. (Kutatási jelentés, kézirat.) - Enyedi Gy. (szerk.), Budapest, MTA RKK.

Beluszky P. (1998) A Felvidék városhálózata a 20. század elején. A Felvidék történeti földrajza. Frisnyák S. (szerk.), Nyíregyháza.

Beluszky P. (1999) Magyarország településföldrajza (Általános rész.). Budapest-Pécs, Dialóg Campus Kiadó.

Benda Gy. (1995) A dunántúli városfejlödés Rúzsás Lajos írásaiban (Rekonstrukcio és értékelés). A Dunántúl szolgálatában. Elöadások Rủzsás Lajos emlékének. - Horváth Gy. (szerk.), Pécs, MTA RKK.

Butlin, R. (1990) Történeti fól drajz, regionális identitás. - Tér és Társadalom. 3-4. 1-11. o.

Erdei F. (1941) A magyar paraszitársadalom. Budapest, Athenaeum.

Erdösi F. (1991) Kommunikáció és térszerkezet. (Területi és telepúlési kutatások 7.) Budapest, Akadémiai Kiadó.

Erdősi F. (1996) A Kárpát-medence kőzlekedési hálózatának alakulási és nemzetkozi kapcsolódásai. $A$ Kárpát-medence történeti földrajza. - Frisnyák S. (szerk.), Nyíregyháza.

Faragó T. (1984) Telepualéstorrténet, tơrténeti taj, tơrténeti térbeliség. - Történeti Statisztikai Tanulmányok 5. 5-38. 0.

Frisnyák S. (1992) Magyarország történeti földrajza. Budapest, Tankönyvkiadó.

Frisnyák S. (1996) Az Árpád-kori Magyarország gazdaságföldrajza - Földrajzi Közlemények 2-3. 119 136. 0 .

Góczán L. (1998) A Kisalfơld. Magyarország földje (Pannon Enciklopédia). - Karátson D. (föszerk.), Budapest, Kertek 2000 Kiadó.

Gyáni G.-Kovér Gy. (1998) Magyarország társadalomtörténete a reformkortól a második világháborúig. Budapest, Osiris Kiadó.

Gyimesi S. (1975) Városok a feudalizmusból a kapitalizmusba való átmenet idốszakában. Budapest, Akadémiai Kiadó.

Hajdú Z. (1996) A magyar kozigazgatás tơrténeti fôldrajza. A Kárpát-medence történeti földrajza. Frisnyák S. (szerk.), Nyíregyháza.

Kalmár G. (1923) A fôldrajzi energiák szerepe Györ telepưlésfoldrajzában. - Földrajzi Közlemények. 1. 57-74. 0.

Kerekes Z. (1923) Szombathely települése. - Földrajzi Közlemények 1. 1-22. o.

Kronsteiner, B. (1989) Zeit, Raum, Struktur. Fernand Braudel und die Geschichtsschreibung in Frankreich. Wien-Salzburg, Geyer-Edition.

Kósa L. (1998) Paraszti polgárosodás és a népi kultuira táji-történeti megoszlása Magyarországon (1880-1920). Budapest, Planétás Kiadó.

Kovér Gy. (1982) Iparosodás agrárországban (Magyarország gazdaságtörténete 1848-1914). Budapest, Gondolat Kiado.

Kővér Gy.(1991) Piacgazdaság - polgárosodás - demokrácia. - Magyar Tudomány 1. 30-46. o.

Majdán J. (1995) Vasúti csomópontok településfejlesztỏ hatása a Dunántúlon. Mezöváros - kisváros. Mikó Zs. (szerk.), Debrecen, Csokonai Kiadó.

Matejka M. (1959) A Kisalfőld fơbb városainak helyzete és funkciói kulönbơzó tơrténelmi szakaszokban. Földrajzi Értesítö. 451-469. o.

Mendol T. (1943) Die Stadt im Karpatenbecken. - Különlenyomat a Földrajzi közlemények nemzetközi kiadásából. 1-143. 0 .

Mendô! T. (1963) Általános településföldrajz. Budapest, Akadémiai Kiadó.

T. Mérey K. (1995) Dunántúli kisvárosok típusai a dualizmus idején. Mezôváros - kisváros. - Mikó Zs. (szerk.), Debrecen, Csokonai Kiadó.

Nemes Nagy J. (1990) Területi kiegyenlítődés és differenciálodás Magyarországon. - Földrajzi Értesitő. 1-4. 133-149. 0.

Nemes Nagy J. (1998) A tér a társadalomkutatásban. (Bevezetés a regionális tudományba) Budapest, Hilscher Rezsó Szociálpolitikai Egyesület.

Princz Gy. (1934) A magyar vásárhelyek. - Földrajzi Közlemények. 1. 51-63. o.

Probáld F. (1995) A regionális foldrajz helye a geográfában (Háttérvázlat). Földrajz, regionális iudomány (Tudományelméleti tanulmányok) Regionális tudományi tanulmányok 2. - Nemes Nagy (szerk.), Budapest, ELTE Regionális Földrajzi Tanszék.

Rétvári L. (1967) Adatok Györ-Sopron megye népességfóldrajzához - Földrajzi Értesitó. 69-89. o.

Rétvári L. (1977) Györ-Sopron megye népesedése. - Földrajzi tanulmányok 15. Budapest, Akadémiai Kiadó.

Rúzsás L. (1963) Városi fejlődés a Dunántúlon a XVIII-XIX. században I. - Különlenyomat a MTA DTI Értekezések 1961-1962. kötetéból. Pécs, MTA DTI. 
Rúzsás L. (I964) Városi fejlődés a Dunántúlon a XVIII-XIX. században II. Különlenyomat a MTA DTI Értekezések 1963 kötetébôl. Pécs, MTA DTI.

Rúzsás L. (1968) A dunántúli védelmi vonal és a paraszt-polgári fejlődés a XVI-XVII. században. Különlenyomat az MTA DTI Értekezések 1967-1968 kótetéból. Pécs, MTA DTI.

Rúzsás L.-Szũcs J. (1966) A várostorténeti kutatás helyzete és feladatai. - Az MTA Társadalmi - Történeti Tudományok Osztályának Közleményei. XV. 1-2. 1-67. 0.

Szörényiné Kukorelli I. (1998) Nyugat-Dunántúli Régio - régio? - Tér és Társadalom. 3. 51-75. 0.

Timaffy L. (1988) A Rábakőz gazdaságtörténete. A Rábaköz térszerkezete. - Rechnitzer J. (szerk.), CsornaKapuvár.

Tímár L. (199I) Regionális gazdaság- és társadalomtorténet vagy torténeti foldrajz? Iparosodás és modernizáció (Tanulmányok Ránki György emlékének). - Mazsu J. (szerk.), Debrecen, KLTE.

Tóth T. (1980) A tơrténeti tájak kérdéséhez. Tamulmányok a terilleti kutatások módszertanából. MTA DTI Kózlemények 27. - Tóth T. (szerk.), Pécs, MTA DTI.

\section{CHANGES IN THE SPATIAL STRUCTURES IN THE KISALFÖLD DURING THE PROCESS OF MIDDLE- CLASSING}

\section{RÓBERT GYÖRI}

The author tries to discover the changes in the spatial structures in the Kisalfold in the $18-19$ centuries. He considers the historical Kisalfold as a spatial structural unit, which is not only an operational instrument for the research but is a functional unit established by real processes formed spatial structure. So this region is not the same with the Kisalfold geographical area, their borders are coincided just partly.

Before the era of the middle-class functional cities and manorial centres that managed the relations overreaching the region border also, were the main centres of the spatial structure. At this time Kisalfold was one of the most modern region of the country connecting to the close Wien in many ways and joining in the European economic system. In this era the importance of administrative centres increased and transportation node function (especially railway) created advantageous situation in the city competition. The whole region has developed and strengthened because of railways meanwhile nodes became the centres of this dynamic system. Nevertheless, the weight of Budapest in Hungary gathered at the same time and its relations extended to this region also, hindering the main cities to obtain national importance.

All this has been reflected in the change of city hierarchy. In the beginning of the 18 century Györ, Pápa, Sopron, Kószeg were in the head of the hierarchy (centre for trade of wine, cattle and other crops). However for 1990 Sopron, Györ and Szombathely became the most important cities of the region (all of them were administrative centres, meeting points of railways and centres of economic and culture). The region hasn't got a clearly definable centre because the three cities divide their functions and manage them together. 